\title{
Industrial Production and Capacity Utilization: The 2004 Annual Revision
}

\section{Charles Gilbert and Kimberly Bayard, of the Board's Division of Research and Statistics, prepared this article. Vanessa Haleco provided research assistance.}

On December 22, 2004, the Board of Governors of the Federal Reserve issued revisions to its index of industrial production (IP) and the related measures of capacity and capacity utilization for the period from January 1972 to November 2004. Overall, the changes to total industrial production were small and almost entirely in the period from 2002 onward (chart 1). ${ }^{1}$ The levels, but not the rates of change, for years before 1972 were also revised.

Note. Charles Gilbert directed the 2004 revision and, with Kimberly Bayard, David Byrne, William Cleveland, Paul Lengermann, Maria Otoo, Dixon Tranum, and Daniel Vine, prepared the revised estimates of industrial production. Norman Morin, John Stevens, and Daniel Vine prepared the revised estimates of capacity and capacity utilization.

1. The production and capacity indexes and the utilization rates referred to in the text and shown in table 1 are based on the data as
Measured from the fourth quarter of 2002 to the third quarter of 2004, industrial output is reported to have increased a little less than shown previously. Production expanded more slowly in 2000 than earlier estimates indicated, whereas the contraction in 2001 was a little less steep. The rise in output in 2002 was slightly stronger than reported earlier.

Although the level of IP was a bit lower in the third quarter of 2004 than previously reported, the rate of industrial capacity utilization - the ratio of production to capacity - was revised upward. At 78.2 percent, the utilization rate for total industry was 0.9 percentage point higher than previously reported but still 2.9 percentage points below its 1972-2003 average. The current figures place the operating rate in manufacturing for the fourth quarter of 2003 and the third quarter of 2004 about $1 / 2$ percentage point above their

published on January 14, 2005. Statements about previously reported estimates refer to the data published in the December 14, 2004, monthly G. 17 release.

1. Total industrial production and capacity utilization, 1998-2004

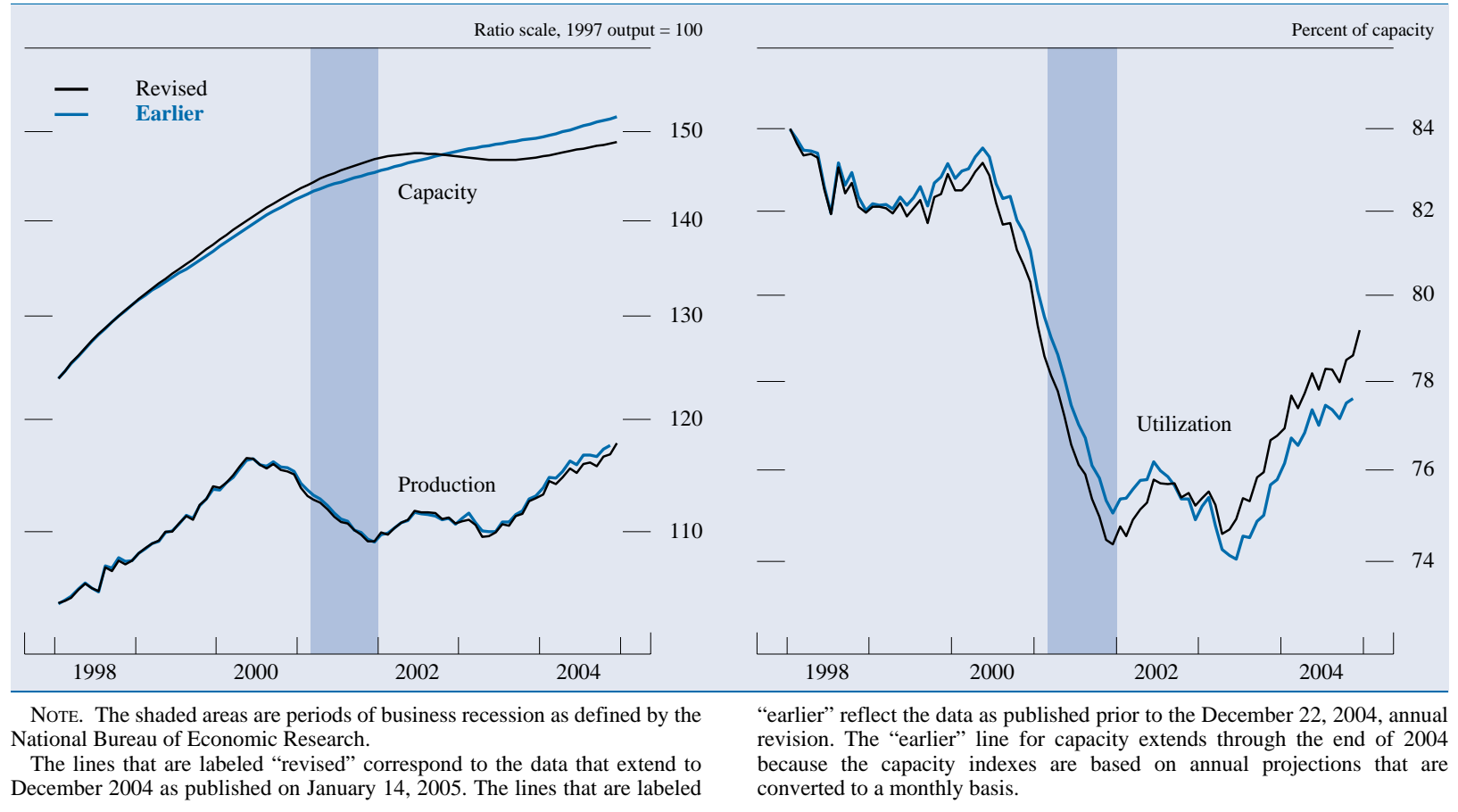


1. Revised rates of change in industrial production and capacity and the revised rate of capacity utilization, 2000-2004

\begin{tabular}{|c|c|c|c|c|c|c|c|c|c|c|c|}
\hline \multirow[t]{2}{*}{ Item } & \multirow{2}{*}{$\begin{array}{c}2003 \\
\text { proportion }\end{array}$} & \multicolumn{5}{|c|}{$\begin{array}{l}\text { Revised rates of change } \\
\text { (percent) }\end{array}$} & \multicolumn{5}{|c|}{$\begin{array}{l}\text { Difference between revised } \\
\text { and earlier rates of change } \\
\text { (percentage points) }\end{array}$} \\
\hline & & 2000 & 2001 & 2002 & 2003 & 2004 & 2000 & 2001 & 2002 & 2003 & 2004 \\
\hline \multicolumn{12}{|l|}{ Production } \\
\hline Total industry ... & 100.0 & 1.9 & -5.1 & 1.5 & 1.2 & 4.2 & -.4 & .2 & .1 & -.3 & -.7 \\
\hline Manufacturing $\ldots \ldots \ldots \ldots \ldots$ & 82.3 & 1.5 & -5.4 & 1.3 & 1.5 & 5.0 & -.5 & .2 & .2 & -.3 & -.9 \\
\hline Excluding high-tech industries .. & 77.4 & -1.9 & -4.9 & .7 & .4 & 4.1 & -.5 & .3 & .8 & -.2 & -.9 \\
\hline High-tech industries $\ldots \ldots \ldots \ldots$ & 4.9 & 37.6 & -10.1 & 8.1 & 18.7 & 18.6 & -.6 & -1.6 & -7.2 & -2.6 & -1.5 \\
\hline Mining and utilities $\ldots \ldots \ldots \ldots \ldots$ & 17.7 & 4.2 & -3.3 & 2.7 & -.4 & .6 & .1 & .2 & -.3 & -.2 & .3 \\
\hline \multicolumn{12}{|l|}{ Capacity } \\
\hline Total industry ... & 100.0 & 4.3 & 2.7 & .5 & -.2 & 1.2 & .2 & .4 & -1.2 & -1.3 & -.4 \\
\hline Manufacturing $\ldots \ldots \ldots \ldots \ldots \ldots$ & 84.9 & 5.0 & 2.6 & .0 & -.1 & 1.1 & .1 & .4 & -1.1 & -1.1 & -.5 \\
\hline Excluding high-tech industries .. & 78.9 & 1.7 & .5 & -.4 & -.6 & .1 & .4 & .1 & -.2 & -.4 & -.1 \\
\hline High-tech industries $\ldots \ldots \ldots \ldots$ & 6.1 & 38.8 & 27.4 & 8.0 & 8.4 & 13.4 & -3.4 & 2.5 & -9.7 & -3.4 & -7.3 \\
\hline Mining and utilities $\ldots \ldots \ldots \ldots \ldots$ & 15.1 & 1.7 & 3.0 & 2.6 & 1.1 & 1.0 & .5 & -.1 & -1.2 & -1.3 & .1 \\
\hline \multicolumn{12}{|l|}{ Capacity utilization (percent) } \\
\hline Total industry...$\ldots \ldots \ldots$ & 100.0 & 80.7 & 74.6 & 75.4 & 76.5 & 78.8 & -.7 & -.8 & .2 & 1.0 & .9 \\
\hline Manufacturing $\ldots \ldots \ldots \ldots \ldots$ & 84.9 & 78.8 & 72.6 & 73.5 & 74.8 & 77.6 & -.8 & -.9 & .1 & .6 & .4 \\
\hline Excluding high-tech industries . & 78.9 & 78.0 & 73.8 & 74.6 & 75.4 & 78.4 & -1.0 & -.7 & .0 & .2 & -.2 \\
\hline High-tech industries $\ldots \ldots \ldots \ldots$ & 6.1 & 86.1 & 60.8 & 60.9 & 66.7 & 69.7 & .3 & -2.2 & -.9 & -.3 & 1.8 \\
\hline Mining and utilities $\ldots \ldots \ldots \ldots$ & 15.1 & 92.5 & 86.8 & 87.0 & 85.7 & 85.3 & -.2 & .0 & .8 & 1.7 & 1.9 \\
\hline
\end{tabular}

is calculated for the period 2003:Q4 to 2004:Q3. The difference in capacity utilization for 2004 refers to 2004:Q3.

earlier estimates. Excluding selected high-technology industries, capacity utilization in manufacturing in 2003 and 2004 was little revised on balance (chart 2). Capacity utilization rates at mines and utilities for the third quarter of 2004 were about 2 percentage points higher than reported earlier.

The revision indicated that industrial capacity expanded at a slower rate in 2002 and 2004 than estimated previously. Capacity is reported to have declined a bit in 2003; previously, a small increase had been reported. The current figures for capacity in 2000 and 2001 indicate a slightly stronger rate of increase than the earlier estimates did.

The updated IP and capacity measures incorporate newly available and more-comprehensive source data. Also, the revision introduced improved methods for compiling sixteen monthly production series and one new capacity series. The annual source data were generally for 2002 and 2003, and the modified methods affected indexes largely from 1972 forward.

The main data source introduced in this annual IP revision was the U.S. Census Bureau's recently issued 2002 Census of Manufactures. Data introduced from other Census Bureau publications included the 2002 Census of Services and the 2003 Services Annual Survey (for publishing) and selected 2003 Current Industrial Reports. Additional government source data included annual data on minerals for 2002 and 2003 from the U.S. Geological Survey (USGS) and updated deflators from the Bureau of Economic Analysis. Also, the new monthly production esti- mates reflect updated seasonal factors and include monthly source data that became available (or were revised) after the closing of the regular four-month reporting window.

The capacity indexes and capacity utilization rates were calculated using the revised production indexes; results from the Census Bureau's 2003 Survey of Plant Capacity for the fourth quarter of the year; and newly available data on industrial capacity from the USGS, the Energy Information Agency of the Department of Energy, and other organizations.

\section{RESULTS OF THE REVISION}

For the third quarter of 2004, total industrial production was reported to be 115.9 percent of output in 1997 (appendix table A.1), and capacity stood at 148.2 percent of output in 1997 (appendix table A.2); both indexes are lower than reported previously. However, because the downward revision to capacity was larger than that to production, the utilization rate for total industry in the third quarter of 2004 was higher than earlier reports suggested.

Appendix tables A.3 and A.4 show the revised rates of change of industrial production for market groups, industry groups, special aggregates, and selected detail for the years 2000 through 2004. Appendix tables A.5, A.6, and A.7 show the revised figures for capacity utilization, capacity, and electric power use. Appendix tables A.3, A.4, A.6, and A.7 
2. High-technology industrial production and capacity utilization

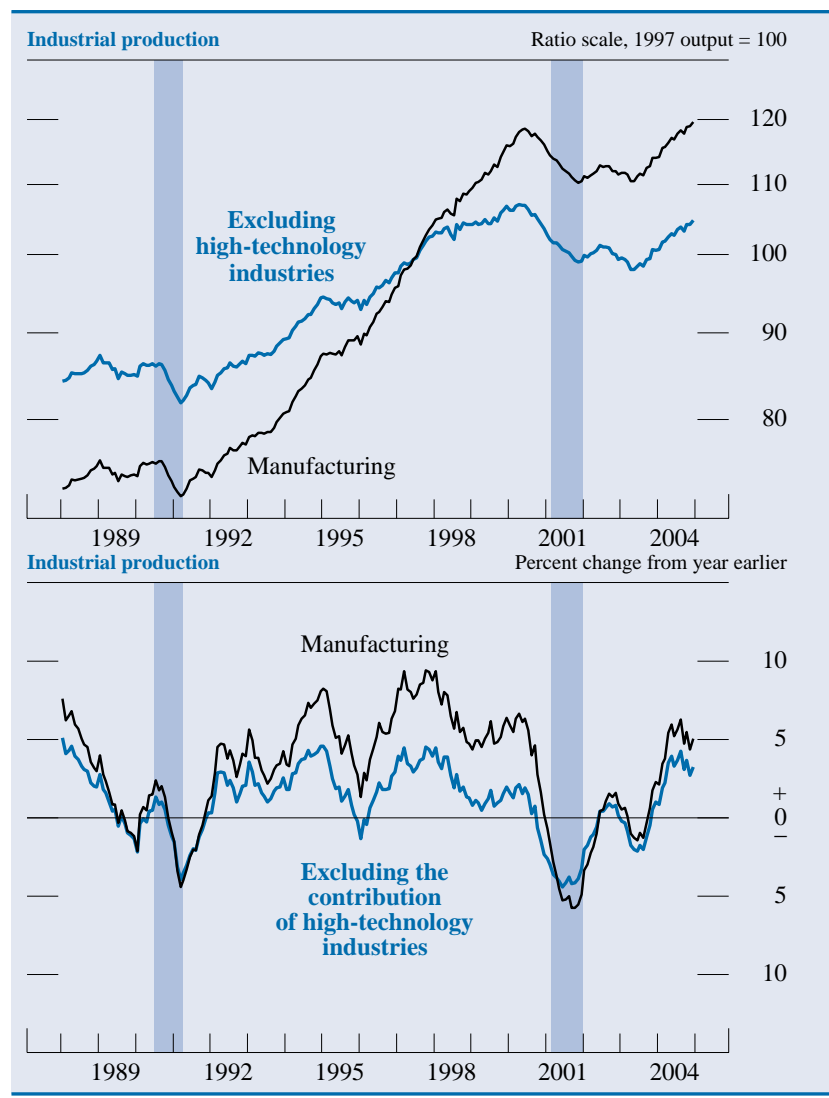

Note. The shaded areas are periods of business recession as defined by the National Bureau of Economic Research.

Manufacturing comprises those industries included in the NAICS definition of manufacturing plus those industries-newspaper, periodical, book, and directory publishing and logging - that have traditionally been considered to be a part of manufacturing and are included in the industrial sector.

show the difference between the revised and earlier rates of change as well. Appendix table A.5 also shows the difference between the revised and previous rates of capacity utilization for the final quarter of the year (the third quarter was used for 2004). Appendix table A. 8 shows the annual proportions of market groups and industry groups in total IP.

\section{Industrial Production}

The revision indicated that the overall path of industrial production was much the same as stated earlier. The most significant feature of this revision-the incorporation of the 2002 Census of Manufactureshad little effect on the top-line estimates.

\section{Production by Industry Groups}

Relative to earlier reports, the current estimates for manufacturing IP indicate a more moderate upward
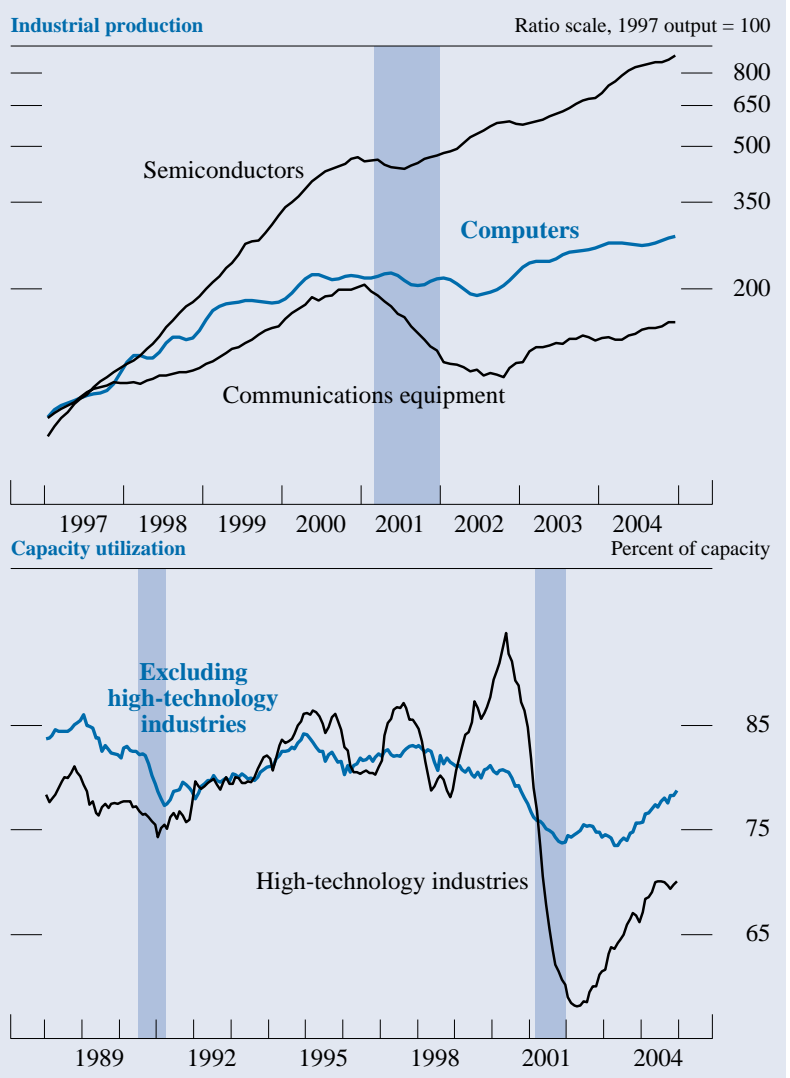

High-technology industries are defined as semiconductors and related electronic components (NAICS 334412-9), computers and peripheral equipment (NAICS 3341), and communications equipment (NAICS 3342).

trajectory for 2003 and 2004. Like the revisions to total industrial production, the revisions to manufacturing output in earlier years were minimal.

Across industry groups, the revision path indicates that the output of durable goods manufacturers followed a generally lower trajectory in recent years than the previous estimates suggested. Industries that contributed to the downward revision in 2003 and 2004 include the computer and electronic products industry, the miscellaneous manufacturing industry, the fabricated metal products industry, the machinery industry, and the wood products industry.

Overall, the index for nondurable manufacturing was a little higher than the previous estimates. In 2004, lower indexes for printing and support; chemicals; plastics and rubber products; and apparel and leather were accompanied by upward revisions to the indexes for petroleum and coal products; food, beverage, and tobacco products; textile and product mills; and paper. 
The revision indicated lower output in recent years for the industries that have historically been defined as manufacturing (namely publishing and logging) but that are classified elsewhere under the North American Industry Classification System (NAICS). The rates of change for 2003 and 2004 are about 4 percentage points lower than previously published.

Regarding a few special aggregates (appendix table A.4), the output of selected high-technology industries-computer and peripheral equipment, communications equipment, and semiconductors and related electronic components-was lower in recent years than previously estimated. Production is reported to have fallen somewhat more steeply in 2001 and to have risen somewhat less in 2002, 2003, and 2004. Relative to earlier estimates, the output of computer and peripheral equipment is estimated to have increased much more slowly in 2002 and 2004 and more quickly in 2003. The index for communications equipment is reported to have declined at a faster pace in 2002 than was reported earlier; the rebound in 2003 is shown to be markedly stronger. The expansion of semiconductor output is estimated to have been much more moderate in 2003 and somewhat stronger in 2004 than earlier estimates suggested.

The revision found somewhat stronger output of motor vehicles and parts in recent years. Relative to earlier estimates, the index rose more in 2002 and 2003.

\section{Production by Market Groups}

Among major market groups, the production index for final products and nonindustrial supplies is little changed from earlier estimates for recent years. The overall path of this index shows a rise in 2000, a dropback in 2001, and then increasingly large gains for 2002 through 2004 (chart 3). The revision strengthened the output of consumer goods for 2001 through 2003; however, the increase in 2004 is estimated to be a little lower. The production of business equipment is reported to be somewhat weaker in the 2000-04 period, on balance, than in the earlier estimates. Production of defense and space equip-

3. Industrial production by market groups, 1988-2004

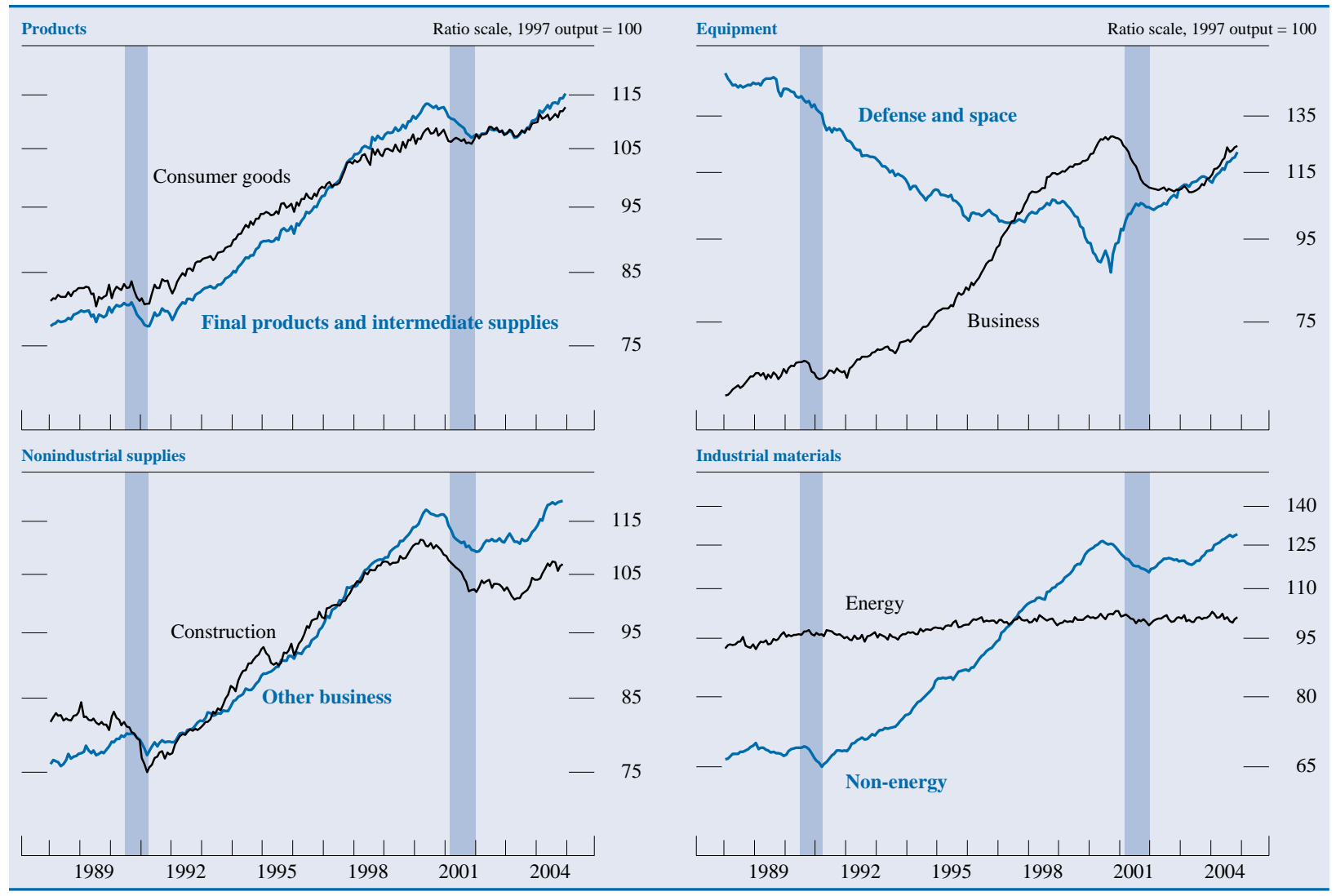

Note. The shaded areas are periods of business recession as defined by the National Bureau of Economic Research. 
ment is reported to have risen a bit less in 2001 than earlier reports suggested, but the overall contour of the index still shows solid gains since 2001. On balance, the index for construction supplies is a little stronger since 2000 than reported earlier. However, the index for business supplies is weaker over the same time period. The output of materials was also weaker in recent years, particularly in 2003 and 2004; production indexes for both the energy and nonenergy categories were revised downward.

\section{Capacity}

The general contour of manufacturing capacity shows a slightly more rapid acceleration during the second half of the 1990s and a sharper deceleration since then. The revisions to the capacity indexes for durable goods industries were the principal contributors to the changes in the contour of manufacturing capacity. The estimates for nondurable manufactures over the same time period are, on balance, little changed from earlier reports.

Among selected high-technology industries, the overall picture of rapidly expanding capacity in the late 1990s followed by more-moderate increases still remains. However, the revision suggested a slower path of expansion in the 2000-04 period than indicated previously. Excluding high-technology industries, manufacturing capacity contracted slightly in 2002 and 2003; the estimates show a small increase for 2004 that is about the same as in the earlier reports.

Capacity at mines decreased in four of the past five years and has declined, on balance, more than previously estimated. In contrast, capacity at electric and gas utilities accelerated sharply from 2000 to 2003, although the current measures show, on balance, a slower rate of expansion than previous estimates. For 2004, the increase in capacity at utilities moderated a bit from the pace seen over the preceding four years.

The revisions to the capacity estimates for stage-ofprocess groups occurred across all groups but were most pronounced in the category for primary and semifinished goods. For 2002 through 2004, the current capacity measures exhibit lower rates of change than previously reported for each stage-of-process group.

\section{Capacity Utilization}

The revised rates of capacity utilization are somewhat higher than the previous estimates for recent years, mainly because of downward revisions to capacity. For the fourth quarter of 2003 and the third quarter of 2004, the revised utilization rates for total industry are about 1 percentage point higher than the earlier estimates. Utilization rates were revised upward for the three major industrial sectorsmanufacturing, mining, and electric and gas utilities-with the revisions concentrated in a few industries in each sector.

Capacity utilization for total industry was 78.8 percent in the fourth quarter of 2004, a level that is 2.3 percentage points below its 1972-2003 average. At 85.6 percent in the fourth quarter, the operating rate for industries in the crude stage of processing was less than 1 percentage point below its long-run average (chart 4). The utilization rates for industries in the primary and semifinished processing group and in the finished processing group for the fourth quarter of 2004 were about 2 percentage points below their respective long-run averages.

Operating rates in manufacturing industries were revised up about $1 / 2$ percentage point in 2003 and in 2004; those changes accounted for about one-half of the upward revisions to total industry capacity utilization in each year. In both 2003 and 2004, some of

\section{Capacity utilization by stage of process, 1967-2004}

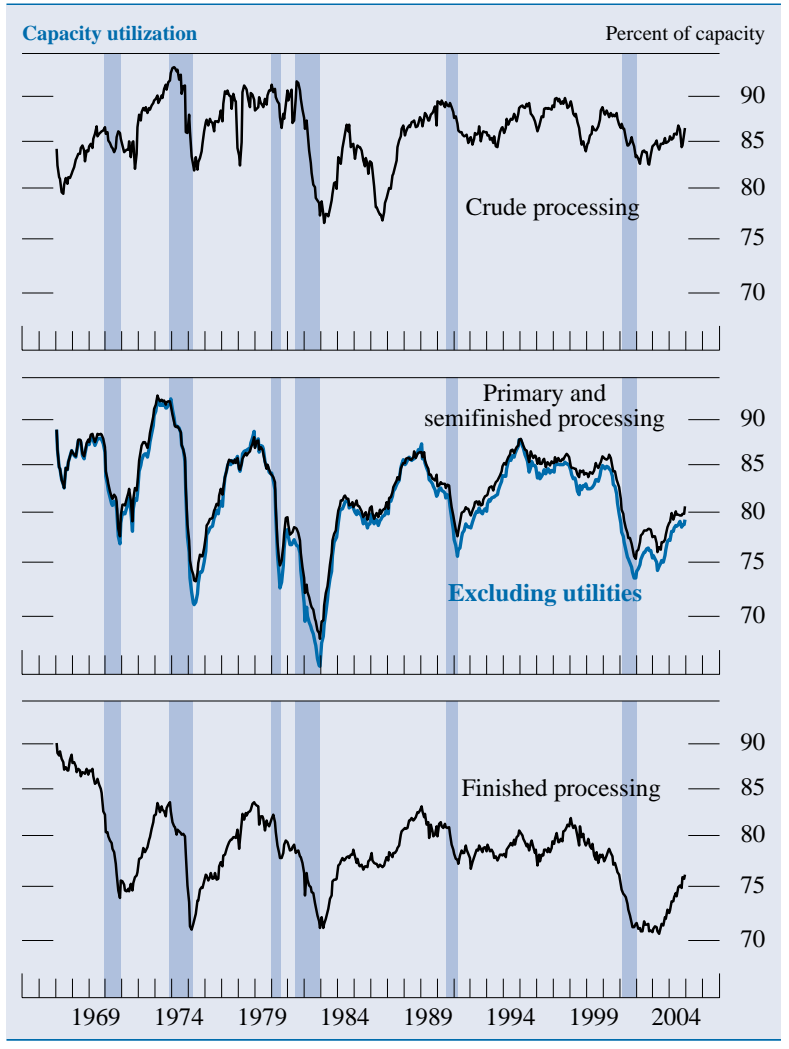

Note. The shaded areas are periods of business recession as defined by the National Bureau of Economic Research. 
5. Capacity utilization for selected high-technology industries, 1995-2004

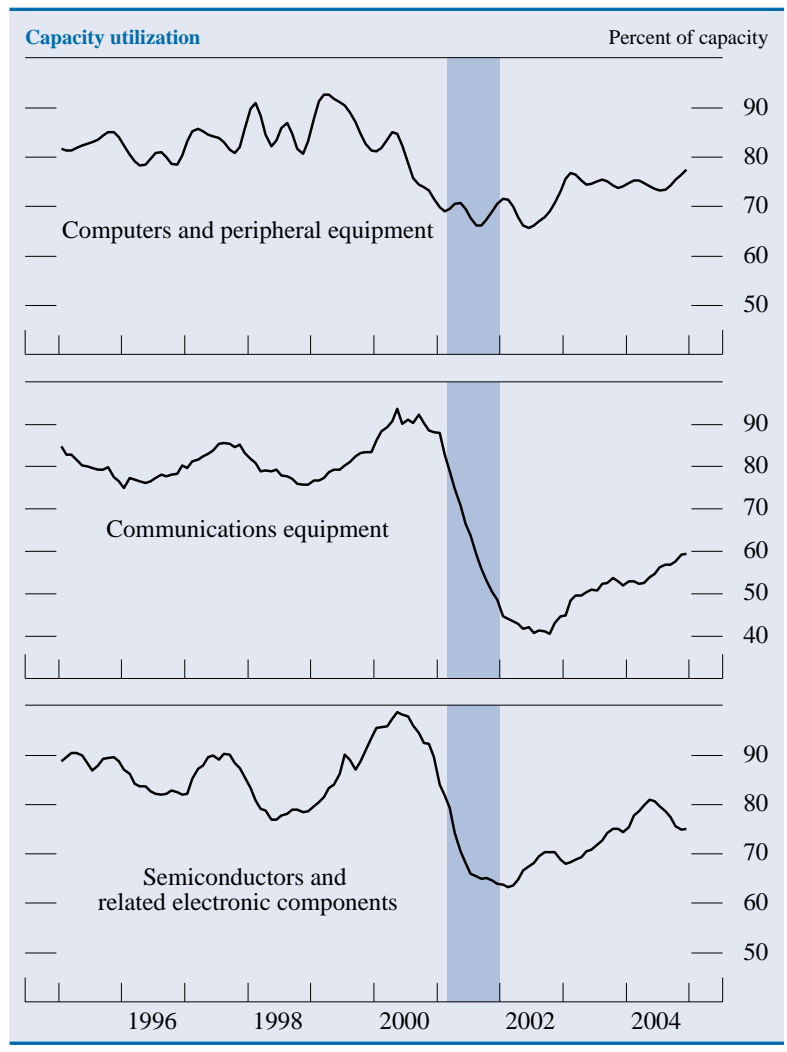

Note. The shaded areas are periods of business recession as defined by the National Bureau of Economic Research.

the upward revision to manufacturing operating rates was attributable to a lower aggregation weight being accorded to high-technology industries; during this time period, the high-technology industries had relatively low utilization rates, but the downward revision to their weight reduced their drag on the overall operating rate. In 2004, the upward revision to manufacturing operating rates was also, in part, attributable to utilization rates in the selected hightechnology industries that were not as low as previously published.

The operating rate for the selected high-technology industries was 69.9 percent in the third quarter of 2004-1.8 percentage points above the previously reported level and 11.6 percentage points above its trough in the second quarter of 2002 (chart 5). On balance for recent years, the revision placed utilization in the semiconductors and related electronic components industry at a higher rate than reported earlier but indicated a lower rate for communications equipment. Operating rates in the computer and peripheral equipment industry were not much changed.
Outside the high-technology industries, manufacturing operating rates in recent years were, on balance, revised little. The current estimates for nondurable goods manufacturers and for durable goods manufacturers excluding the high-technology industries are little changed in 2003 and 2004. Over the same period, particularly for 2004, the utilization rates for other (non-NAICS) manufacturers are lower than earlier estimates suggested.

Outside of manufacturing, the revision placed the utilization rates for mines and for electric and gas utilities at higher levels than reported earlier. The upward revisions to the utilization rates for utilities reflect a significant downward revision to the data on electricity generation capacity. Less capacity at coal mines and an upward revision to drilling activity yielded higher operating rates in these industries that more than offset downward revisions to utilization rates elsewhere in mining. For the third quarter of 2004, the utilization rate at mines was 86.3 percent, and the utilization rate at gas and electric utilities was 83.7 percent. Both measures are still below their 1972-2003 averages but roughly 2 percentage points above their previous estimates.

\section{TECHNICAL ASPECTS OF THE REVISION}

The revision incorporated updated comprehensive annual data and revised monthly source data used in the estimation of production, capacity, and utilization. As noted earlier, the revision included information drawn from the recently released 2002 Census of Manufactures. Additionally, this revision incorporated the 2003 Survey of Plant Capacity, other annual industry reports, recent information on prices, and revised monthly source data measuring physical output and labor and electricity inputs to production. Along with the individual production series and seasonal factors, the annual value-added weights used in aggregating the indexes to market and industry groups were also updated.

\section{Changes to Benchmark Indexes}

The benchmark indexes for manufacturing-defined for each six-digit NAICS industry as nominal gross output divided by a price index-were modified in the revision. The principal change to the indexes was the inclusion of new information from the 2002 Census of Manufactures and revisions to the information in the 2001 Annual Survey of Manufactures. In addition, the benchmark indexes incorporated newly 
available price indexes on a NAICS basis from the Bureau of Economic Analysis (BEA). The new price data were not significantly different from the estimates that had been used previously. The calculation of nominal gross output for the benchmark indexes was also revised for 1997 to the present. Previously, nominal gross output for an industry was defined to equal cost of materials plus value added. The updated methodology subtracts from that figure the cost of resold goods (those goods purchased by a manufacturer and then resold without any material transformation).

\section{Changes to Individual Production Series}

With the revision, the monthly production indicators for some series have changed. The source data for eleven industries were switched from electric power use to production-worker hours. These industries, which constituted 6.6 percent of IP in 2003, are the following:

1. other animal food (NAICS 311119)

2. soft drink and ice (31211)

3. wood container and pallet (32192)

4. paving, roofing, and other petroleum and coal products $(32412,9)$

5. pesticide and other agricultural chemicals (32532)

6. concrete and product (32732-9)

7. forging and stamping (3321)

8. coating, engraving, heat treating, and allied activities (3328)

9. motor vehicle metal stamping (33637)

10. household and institutional furniture and kitchen cabinet (3371)

11. medical equipment and supplies (3391)

The decision to switch the monthly indicators for these industries resulted from a deterioration in the sample of utilities that report for these industries as well as from a review of the historical annual relationships between the output benchmarks and the two corresponding inputs to production.

The revision also incorporated new physical product indicators for five industries, which made up 1.4 percent of IP in 2003:

1. aluminum foundries (NAICS 331521,4 )

2. machine tools $(333512,3)$

3. engine manufacturing (333618)

4. mattress manufacturing (33791)

5. book publishing (51113)
Previously, these industries were combined with other industries in single IP indexes and then estimated from production-worker hours. Although not published, the additional series raised the total number of individual output indexes that make up industrial production to 300 .

The aluminum foundries industry (NAICS $331521,4)$ was formerly grouped with other nonferrous foundries in a single IP index based on production-worker hours. For 1992 and forward, this revision established separate indexes for aluminum foundries and for other nonferrous foundries. The production indicator for the new index for aluminum foundries is a value-weighted aggregate of quarterly shipments of dies, permanent molds, sand castings, and other castings, for which the underlying data are obtained from the Aluminum Association. In 2003, dies made up 56.5 percent of the total product value of this industry, sand castings made up 21.4 percent, permanent molds made up 21.9 percent, and the other castings made up the very small remainder. These data are available from 1994 forward; the indexes for 1992 and 1993 were estimated based on productionworker hours. The separate index for other nonferrous foundries $(331522,5,8)$ is based on productionworker hours.

The machine tools industry (metal cutting and forming machinery, NAICS 333512,3) was formerly grouped with other metalworking machinery in a single IP index based on production-worker hours. For 1992 and forward, the revision introduced a new index for the machine tool industry that is based on quarterly shipments data from the Census Bureau. Other metalworking machinery $(333511,4,5,6,8)$ is now a separate index based on production-worker hours. The Census Bureau's Current Industrial Report on Metalworking Machinery (MQ333W) provides data on shipments for a variety of machine tools, including boring and drilling machines; gearcutting machines; grinding and polishing machines; lathes; milling machines; machining centers; punching, shearing, bending, and forming machines; and presses. Both unit and revenue measures for shipments are used to construct a Fisher index of real shipments. A model-based estimate of the change in inventories (see box "The Estimation of Inventories for the Machine Tool Industry") is then added to the shipments index to compute a production index.

Engine manufacturing (NAICS 333618) was formerly grouped with power transmission equipment in a single IP index based on production-worker hours. For 1992 and forward, engines and power transmission equipment are separate indexes. The NAICS industry 333618 comprises manufacturers of 


\section{The Estimation of Inventories for the Machine Tools Industry}

In the inventory model used in the estimation of machine tool production, manufacturers are assumed to want to hold inventories proportional to their expected shipments. The estimate of inventory change is computed as the sum of three components: a trend rate of stockbuilding, a portion of the adjustment to inventories that a manufacturer would need to make in order to reach a desired inventory level, and the impact on stocks of a deviation of shipments from expectations. Three parameters are required for the model: (1) a target for the ratio of inventories to expected sales, (2) a parameter that indicates how quickly manufacturers try to make up the deviation from their target inventory level at the end of the previous quarter, and (3) a parameter that indicates the degree to which surprises in shipments are offset by changes in actual production in the same quarter. The parameters values were chosen by examining industries for which shipments data exist and either production or inventory data exist. The primary criterion for the selection of parameter values was to maximize the $R^{2}$ statistic attained when regressing the period-to-period rate of change for the seasonally adjusted production series on the rate of change for the output estimate from the model (which is equal to shipments plus the model's estimate of the change in inventories). In addition to just maximizing the average $R^{2}$ statistic over all of the industries examined, it was also undesirable for the $R^{2}$ statistic to decrease rapidly as a result of small perturbations in the parameter values. The parameters that resulted from this estimation procedure seemed plausible. The target for the ratio of inventories to expected shipments was selected to be 0.3 quarter, or equivalently one month, of supply. Surprises in shipments were estimated to be mostly offset by production changes within a quarter-only 20 percent of the surprise feeds through to inventories by the end of the quarter. Last, it was estimated that during a quarter, manufacturers try to close about 40 percent of any gap between actual and target inventory levels that existed at the beginning of the quarter.

internal combustion engines except those who produce automotive gasoline engines or aircraft engines. Monthly diesel engine assemblies from Stark Communications, Inc., provide the production indicator for the new index for engines. The remainder of the previous grouping-speed changers, drives, gears, and power transmission equipment (NAICS 333612,3) - is now a separate index and is still based on production-worker hours.

The output of mattresses (NAICS 33791) was formerly grouped with the output of blinds and shades (NAICS 33792) in a single IP index called "Other furniture related product," and the estimates were based on production-worker hours. Under the revision, mattress production for 1987 and forward is based on monthly unit sales data for mattresses and foundations from the International Sleep Products Association (ISPA). The blinds and shades index continues to be based on production-worker hours.

The ISPA data come from a monthly survey of leading producers of mattresses and foundations. According to the ISPA, survey respondents in 2003 represented more than 60 percent of industry unit shipments and nearly 75 percent of wholesale dollar sales. In addition to providing information from survey respondents, the organization estimates shipments and sales for the industry as a whole. The ISPA issues information separately for mattresses and for foundations; however, currently not enough history exists for the two components to be independently weighted.

Previously, the output of the book publishing industry (NAICS 51113) was grouped with the output of other publishing operations except newspapers $(51112,4,9)$ into a single index called "Periodical, book, and other publishers" and was based on production-worker hours. The revision introduced a new index for book publishing that begins in 1987 and is estimated separately from the other publishing operations. The new index for periodicals and other publishers is based on production-worker hours.

The new index for the book publishing industry is based on gross sales listed in the monthly reports issued by the Association of American Publishers. A Fisher index of real sales is constructed from sixteen separate categories of books and is used as the indicator for the book publishing series. The underlying gross revenue data are deflated by detailed producer price indexes from the Bureau of Labor Statistics. Because of the volatility of the sales data, the monthly production index is a three-month centered moving average in which the data for the second month are more heavily weighted than are the data for the first or third month.

The new book publishing index will continue to be published as part of the aggregate index for "Periodical, book, and other publishers" (NAICS 51112-9). Book publishing comprises approximately 20 percent of the aggregate index and about 1 percent of total IP.

Table 2 shows the 2003 value-added proportion of data by type available in each month of the fourmonth IP publication window. The first estimate of output for a month is preliminary and is subject to revision in each of the subsequent three months as new source data become available. As the table indicates, by the third revision (the fourth month of 
2. Proportion of industrial production data by type in reporting window, 2003 Percent

\begin{tabular}{crrrr}
\hline \multirow{2}{*}{ Type of source data } & \multicolumn{4}{c}{ Month of estimate } \\
\cline { 2 - 5 } & \multicolumn{1}{c}{ 1st } & 2nd & 3rd & \multicolumn{2}{c}{ 4th } \\
\hline Physical product $\ldots \ldots \ldots \ldots \ldots \ldots$ & 26.1 & 40.8 & 49.9 & 50.1 \\
Production-worker hours $\ldots \ldots \ldots \ldots$ & 34.7 & 34.7 & 34.7 & 34.7 \\
Electric power use $\ldots \ldots \ldots \ldots \ldots \ldots$ & .0 & 11.7 & 11.7 & 11.7 \\
Received $\ldots \ldots \ldots \ldots \ldots \ldots \ldots \ldots$ & $\mathbf{6 0 . 8}$ & $\mathbf{8 7 . 2}$ & $\mathbf{9 6 . 4}$ & $\mathbf{9 6 . 6}$ \\
Estimated $\ldots \ldots \ldots \ldots \ldots \ldots \ldots \ldots$ & $\mathbf{3 9 . 2}$ & $\mathbf{1 2 . 8}$ & $\mathbf{3 . 6}$ & $\mathbf{3 . 4}$ \\
Total industrial production $\ldots \ldots$ & $\mathbf{1 0 0 . 0}$ & $\mathbf{1 0 0 . 0}$ & $\mathbf{1 0 0 . 0}$ & $\mathbf{1 0 0 . 0}$ \\
\hline
\end{tabular}

an estimate), the physical-product content of IP is 50.1 percent.

The revision incorporated refined methods for a few series. The coverage was broadened for some of the motor vehicles parts series to include more information for engines, brakes, transmissions, and axles. This revision also included new methods for the production indicator for electronic computers; the new estimates incorporate a refined concordance between trade data from the Census Bureau and the source data for computer sales.

\section{LAN Equipment}

The 2000 revision introduced a new IP series for the production of local area network (LAN) equipment (routers, switches, and hubs). The series is not published in the monthly statistical release, but it is included in the broader IP aggregate for communications equipment and updated on an ongoing basis. ${ }^{2}$ Table 3 updates the results for LAN equipment.

\section{Changes to Individual Capacity Series}

The revision to the capacity indexes used updated information for the publishing industry, for which there had been a gap in the collection of operating rates. Through 1998, the Survey of Plant Capacity (SPC), which covers the manufacturing sector, was conducted under the Standard Industrial Classification (SIC) system. The SIC system included the publishing industry in the manufacturing sector. In 1999, the SPC began to be conducted under NAICS, which excludes the publishing industry from the manufacturing sector. In 2002, the Census Bureau recommenced collection of publishing industry data under the SPC. The release of the 2003 SPC provided

2. Carol Corrado, "Industrial Production and Capacity Utilization: The 2000 Annual Revision," Federal Reserve Bulletin, vol. 87 (March 2001), pp. 132-48, (www.federalreserve.gov/pubs/bulletin/ 2001/0301scnd.pdf).
3. U.S. LAN equipment, 1997-2003

\begin{tabular}{|c|c|c|c|}
\hline Period & $\begin{array}{l}\text { Production } \\
\text { index }\end{array}$ & $\begin{array}{l}\text { Price } \\
\text { index }\end{array}$ & $\begin{array}{l}\text { Value of } \\
\text { production } \\
\text { (millions } \\
\text { of dollars) }\end{array}$ \\
\hline \multicolumn{4}{|l|}{$\begin{array}{l}\text { Annual estimates } \\
(1997=100)\end{array}$} \\
\hline $1997 \ldots \ldots \ldots \ldots$ & 100.0 & 100.0 & $12,935.4$ \\
\hline 1998 & 153.2 & 72.2 & $14,329.5$ \\
\hline$\ldots \ldots \ldots \ldots \ldots$ & 223.0 & 59.1 & $17,138.9$ \\
\hline 2000 & 303.5 & 52.5 & $20,732.7$ \\
\hline 2001 . & 357.9 & 41.2 & $19,205.4$ \\
\hline 2002. & 366.6 & 32.8 & $15,635.1$ \\
\hline 2003 & 412.5 & 25.4 & $13,549.1$ \\
\hline \multicolumn{4}{|l|}{$\begin{array}{l}\text { Quarterly estimates } \\
(1997=100)\end{array}$} \\
\hline 1997:Q1 ........ & 77.7 & 108.0 & $10,767.2$ \\
\hline Q2 & 88.8 & 97.4 & $11,634.7$ \\
\hline Q3 .. & 109.2 & 97.5 & $13,824.5$ \\
\hline $\mathrm{Q} 4$................... & 124.3 & 97.9 & $15,423.2$ \\
\hline 1998:Q1 & 136.7 & 80.2 & $14,120.6$ \\
\hline Q2 & 154.8 & 71.1 & $15,041.5$ \\
\hline Q3 $\ldots \ldots \ldots \ldots \ldots \ldots$ & 160.7 & 67.6 & $14,009.2$ \\
\hline $\mathrm{Q} 4$.................... & 160.7 & 69.7 & $14,191.5$ \\
\hline 1999:Q1 .. & 212.4 & 61.6 & $16,984.3$ \\
\hline Q2 ... & 225.2 & 56.3 & $17,383.2$ \\
\hline ............. & 224.4 & 59.8 & $17,086.5$ \\
\hline Q4 $\ldots$ & 229.8 & 58.6 & $17,138.6$ \\
\hline 2000:Q1 & 262.8 & 54.4 & $18,692.5$ \\
\hline Q2 & 304.4 & 49.8 & $20,542.1$ \\
\hline Q3 $\ldots$ & 322.9 & 53.5 & $21,751.7$ \\
\hline $\mathrm{Q} 4 \quad \ldots \ldots \ldots \ldots \ldots$ & 323.8 & 52.7 & $21,853.8$ \\
\hline 2001:Q1 & 391.3 & 43.1 & $22,253.4$ \\
\hline Q2 & 336.8 & 42.2 & $18,933.4$ \\
\hline $\mathrm{Q} 3{ }^{2} \ldots \ldots \ldots \ldots \ldots \ldots \ldots \ldots$ & 340.3 & 41.6 & $17,741.7$ \\
\hline $\mathrm{Q} 4 \ldots \ldots \ldots \ldots \ldots \ldots \ldots$ & 363.4 & 38.0 & $17,938.4$ \\
\hline 2002:Q1 .. & 353.9 & 34.5 & $16,381.3$ \\
\hline Q2 .. & 360.0 & 33.5 & $16,034.4$ \\
\hline $\mathrm{Q} 3{ }^{3}, \ldots \ldots \ldots \ldots \ldots \ldots \ldots$ & 382.2 & 33.1 & $15,683.9$ \\
\hline $\mathrm{Q} 4$.................... & 370.2 & 30.2 & $14,438.5$ \\
\hline 2003:Q1 $\ldots \ldots \ldots \ldots \ldots \ldots \ldots$ & 374.3 & 26.5 & $13,514.5$ \\
\hline $\mathrm{Q} 2 \ldots \ldots \ldots \ldots \ldots \ldots \ldots$ & 400.6 & 27.0 & $14,365.4$ \\
\hline 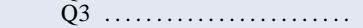 & 434.5 & 26.2 & $13,993.9$ \\
\hline Q4 $\ldots \ldots \ldots \ldots \ldots \ldots$ & 440.7 & 21.7 & $12,336.1$ \\
\hline
\end{tabular}

the Federal Reserve Board with two consecutive data points for the publishing industry and enabled the interpolation of industry information for the missing years 1999-2001.

The revisions to the capacity indexes also incorporated the BEA's capital flow table for 1997. This table provided a detailed breakdown of the asset composition of industry investment. The Federal Reserve used the capital flow table to estimate annual asset-by-industry investment flows - which is the first step in constructing measures of industry capital input. Before the current revision, the Federal Reserve used data for thirty-five asset categories; this revision added a thirty-sixth, software investment.

Finally, the capacity series for semiconductors was split into two components. One covers microprocessor units (MPUs), and the other covers non-MPU semiconductors, such as memory, logic, and other integrated circuit chips. Neither component will be published. 


\section{Weights for Aggregation}

The IP index is an annually weighted Fisher index. This revision used information from the Census of Manufactures to obtain updated estimates of the industry value-added weights for the aggregation of IP indexes and capacity utilization rates. The Federal Reserve derives estimates of value added for the electric and gas utility industries from annual revenue and expense data issued by other organizations.

The weights for aggregation, expressed as unit value added, were estimated using the latest data on producer prices. Appendix table A.8 shows the annual value-added proportions incorporated in the IP index from 1996 through 2004.

\section{Revised Monthly Data}

The revision incorporated product data that became available after the regular four-month reporting window for monthly IP had closed. One example is the data on wine and tobacco issued by the Department of the Treasury's Alcohol and Tobacco Tax and Trade
Bureau. These data were released with too great a lag to be incorporated in the monthly IP estimates; however, the data were available for inclusion in the annual revision.

\section{Revised Seasonal Factors}

Seasonal factors for all series were reestimated using data that extend into 2004. Factors for productionworker hours, which adjust for timing, holiday, and monthly seasonal patterns, were updated with data through September 2004 and were prorated to correspond with the seasonal factors for hours aggregated to the three-digit NAICS level. Factors for the electric power series were reestimated using data through June 2004. The updated factors for the physical product series, which include adjustments for holiday and workday patterns, used data through at least September 2004. Seasonal factors for unit motor vehicle assemblies have been updated, and projections through June 2005 are on the Board's website at www.federalreserve.gov/releases/g17/mvsf.htm. 
A.1. Revised data for industrial production for total industry

Seasonally adjusted data except as noted

\begin{tabular}{|c|c|c|c|c|c|c|c|c|c|c|c|c|c|c|c|c|c|}
\hline \multirow{2}{*}{ Year } & \multirow{2}{*}{ Jan. } & \multirow{2}{*}{ Feb. } & \multirow{2}{*}{ Mar. } & \multirow{2}{*}{ Apr. } & & & & & & & & & & $\mathrm{Qu}$ & rter & & \\
\hline & & & & & May & June & July & Aug. & Sept. & Oct. & Nov. & Dec. & 1 & 2 & 3 & 4 & avg. ${ }^{1}$ \\
\hline & & & & & & & Indus & ial pro & action ( & ercent cl & ange) & & & & & & \\
\hline 1972 & 2.4 & .9 & .8 & 1.0 & .0 & .3 & .1 & 1.3 & .8 & 1.3 & 1.1 & 1.2 & 17.8 & 7.9 & 5.7 & 14.6 & 9.6 \\
\hline 1973 & .6 & 1.5 & .0 & -.2 & .7 & .1 & .4 & -.1 & .9 & .6 & .5 & -.3 & 11.7 & 3.2 & 3.7 & 5.8 & 8.2 \\
\hline 1974 & -.7 & -.3 & .0 & -.1 & .6 & -.1 & .1 & -.9 & .1 & -.4 & -3.3 & -3.5 & -3.8 & .4 & -1.7 & -14.9 & -.4 \\
\hline 1975. & -1.3 & -2.4 & -1.0 & .0 & -.1 & .7 & 1.1 & .9 & 1.3 & .4 & .3 & 1.3 & -23.9 & -5.5 & 10.7 & 8.8 & -8.9 \\
\hline 1976 & 1.4 & .9 & .0 & .7 & .4 & .0 & .6 & .7 & .2 & .1 & 1.5 & 1.0 & 12.5 & 5.2 & 5.1 & 7.8 & 7.8 \\
\hline 1977 & -.6 & 1.5 & 1.2 & .9 & .8 & .7 & .3 & .1 & .5 & .3 & .1 & .1 & 8.4 & 12.5 & 5.1 & 3.2 & 7.7 \\
\hline 1978 & -1.4 & .5 & 1.9 & 1.9 & .4 & .7 & .0 & .4 & .3 & .8 & .8 & .6 & -1.5 & 16.3 & 3.6 & 7.7 & 5.5 \\
\hline 1979 & -.7 & .6 & .3 & -1.0 & .7 & .0 & -.2 & -.7 & .1 & .5 & -.1 & .2 & 1.8 & -.5 & -1.5 & 1.4 & 3.0 \\
\hline 1980 & .4 & .0 & -.4 & -2.0 & -2.5 & -1.3 & -.6 & .3 & 1.6 & 1.2 & 1.7 & .6 & 1.5 & -15.9 & -6.2 & 15.9 & -2.6 \\
\hline 1981 & -.5 & -.5 & .5 & -.4 & .7 & .5 & .7 & .0 & -.7 & -.7 & -1.1 & -1.1 & .9 & 1.4 & 4.2 & -8.6 & 1.3 \\
\hline 1982 & -1.9 & 1.9 & -.7 & -.8 & -.7 & -.4 & -.4 & -.8 & -.4 & -.8 & -.4 & -8 & -7.5 & -5.0 & -6.0 & -7.6 & -5.1 \\
\hline 1983 & 1.9 & -6 & .9 & 1.2 & .7 & .6 & 1.6 & 1.1 & 1.6 & .8 & .3 & .5 & 4.4 & 9.4 & 14.8 & 10.9 & 2.6 \\
\hline 1984 & 2.1 & 4 & .5 & .6 & .5 & .4 & .3 & .1 & -.2 & -.1 & 4 & .1 & 12.5 & 6.2 & 2.9 & .5 & 9.0 \\
\hline 1985 & -.3 & .4 & .1 & -.2 & .1 & .0 & -.7 & .5 & .4 & -.4 & .3 & 1.0 & 1.1 & .5 & -.7 & 2.6 & 1.3 \\
\hline 1986 & .5 & -.8 & -.6 & .0 & .2 & -.3 & .6 & -.2 & .2 & .4 & .5 & .9 & 2.4 & -2.6 & 1.6 & 4.6 & 1.0 \\
\hline 1987 & -.3 & 1.3 & .1 & .6 & .7 & .5 & 6 & .7 & .2 & 1.5 & .5 & .5 & 5.5 & 7.0 & 7.0 & 9.8 & 5.1 \\
\hline 1988 & .0 & .4 & .3 & .5 & -.1 & .2 & .2 & .5 & -.3 & .6 & .2 & .4 & 3.4 & 3.3 & 2.1 & 3.2 & 5.0 \\
\hline 1989 & .3 & -.5 & .3 & -.1 & -.7 & .0 & -.9 & 1.0 & -.3 & .0 & .3 & .7 & 1.5 & -1.9 & -2.5 & 2.0 & .9 \\
\hline 1990 & -.6 & .9 & .5 & .0 & .1 & .3 & -.2 & .3 & .2 & -.7 & -1.2 & -.7 & 2.6 & 2.9 & 1.3 & -5.9 & .9 \\
\hline 1991 & -.5 & -.6 & -.5 & .2 & 1.0 & 1.0 & .0 & .1 & .8 & -.2 & -.1 & -.3 & -7.5 & 2.6 & 5.6 & .9 & -1.5 \\
\hline 1992 & -.6 & .7 & .8 & .7 & .5 & .0 & 8 & -.4 & .2 & .7 & .4 & .0 & -.3 & 7.1 & 2.7 & 3.9 & 2.8 \\
\hline 1993 & .5 & .4 & .0 & .3 & -.4 & .2 & .3 & .1 & .4 & .7 & .5 & .5 & 3.7 & 1.1 & 2.2 & 6.3 & 3.3 \\
\hline 1994 & .4 & .0 & 1.0 & .5 & .6 & .7 & .2 & .5 & .2 & .9 & .6 & 1.1 & 5.2 & 7.5 & 5.2 & 8.1 & 5.4 \\
\hline 1995 & .3 & .0 & .1 & .0 & .2 & .3 & -.4 & 1.4 & .4 & -.2 & .2 & .5 & 5.2 & 1.0 & 3.8 & 3.7 & 4.8 \\
\hline 1996 & -.9 & 1.5 & -.2 & .9 & .7 & .9 & -.1 & .7 & 6 & .1 & 9 & .7 & 1.7 & 8.3 & 5.5 & 6.4 & 4.3 \\
\hline 1997 & .3 & 1.2 & .5 & .2 & .4 & .5 & .6 & 1.0 & .9 & .8 & 6 & .4 & 8.6 & 5.7 & 8.6 & 9.5 & 7.3 \\
\hline 1998 & .5 & .2 & .2 & 6 & .5 & -.4 & $\begin{array}{r}.0 \\
-.2\end{array}$ & 1.9 & -.3 & .8 & -.2 & .2 & 4.6 & 4.3 & 3.4 & 4.5 & 5.8 \\
\hline 1999 & .6 & .4 & .4 & .2 & .7 & .0 & .6 & 6 & -.3 & 1.2 & .5 & 1.0 & 4.4 & 4.3 & 4.7 & 7.4 & 4.5 \\
\hline 2000 & -.1 & .4 & .6 & .7 & 6 & .0 & -.5 & -3 & .4 & -.5 & -.1 & -.2 & 4.7 & 6.7 & -1.4 & -2.0 & 4.3 \\
\hline 2001 & -1.0 & -.6 & -.3 & -.2 & -.5 & -.6 & -.4 & -.1 & -.5 & -.4 & -.5 & .0 & -6.7 & -4.6 & -4.7 & -4.2 & -3.6 \\
\hline 2002 & .7 & -.2 & .6 & .4 & .2 & .7 & -.1 & .0 & .0 & -.5 & .1 & -.4 & 2.3 & 4.4 & 1.7 & -2.3 & -.3 \\
\hline 2003 & .2 & .1 & -.4 & -.9 & .1 & .3 & 6 & -.1 & .7 & .2 & 1.0 & .2 & -.7 & -4.0 & 4.1 & 5.7 & .0 \\
\hline 2004 & .3 & 1.1 & -.3 & .5 & .7 & -.4 & .7 & .1 & -.3 & .8 & .2 & .8 & 5.6 & 4.3 & 2.7 & 4.1 & 4.1 \\
\hline & & & & & & & Ind & strial pr & duction & $1997=$ & 00) & & & & & & \\
\hline 1972 & 50.0 & 50.4 & 50.8 & 51.3 & 51.3 & 51.5 & 51.5 & 52.2 & 52.6 & 53.3 & 53.9 & 54.5 & 50.4 & 51.4 & 52.1 & 53.9 & 51.9 \\
\hline 1973 & 54.9 & 55.7 & 55.7 & 55.5 & 55.9 & 56.0 & 56.2 & 56.2 & 56.6 & 57.0 & 57.3 & 57.1 & 55.4 & 55.8 & 56.3 & 57.1 & 56.2 \\
\hline 1974 & 56.7 & 56.5 & 56.5 & 56.5 & 56.8 & 56.7 & 56.8 & 56.2 & 56.3 & 56.1 & 54.2 & 52.3 & 56.6 & 56.7 & 56.4 & 54.2 & 56.0 \\
\hline 1975 & 51.6 & 50.4 & 49.8 & 49.8 & 49.8 & 50.1 & 50.6 & 51.1 & 51.8 & 52.0 & 52.1 & 52.8 & 50.6 & 49.9 & 51.2 & 52.3 & 51.0 \\
\hline 1976 & 53.5 & 54.0 & 54.0 & 54.4 & 54.6 & 54.6 & 54.9 & 55.3 & 55.4 & 55.5 & 56.3 & 56.9 & 53.8 & 54.5 & 55.2 & 56.3 & 55.0 \\
\hline 1977 & 56.6 & 57.4 & 58.1 & 58.7 & 59.1 & 59.5 & 59.7 & 59.8 & 60.1 & 60.3 & 60.3 & 60.4 & 57.4 & 59.1 & 59.9 & 60.3 & 59.2 \\
\hline 1978 & 59.5 & 59.8 & 60.9 & 62.1 & 62.4 & 62.8 & 62.8 & 63.0 & 63.2 & 63.7 & 64.2 & 64.6 & 60.1 & 62.4 & 63.0 & 64.1 & 62.4 \\
\hline 1979 & 64.1 & 64.5 & 64.7 & 64.0 & 64.5 & 64.5 & 64.4 & 63.9 & 64.0 & 64.3 & 64.3 & 64.4 & 64.4 & 64.3 & 64.1 & 64.3 & 64.3 \\
\hline 1980 & 64.6 & 64.7 & 64.4 & 63.2 & 61.6 & 60.8 & 60.4 & 60.6 & 61.6 & 62.3 & 63.4 & 63.7 & 64.6 & 61.8 & 60.9 & 63.1 & 62.6 \\
\hline 1981 & 63.4 & 63.1 & 63.4 & 63.1 & 63.6 & 63.9 & 64.3 & 64.3 & 63.9 & 63.4 & 62.7 & 62.1 & 63.3 & 63.5 & 64.2 & 62.7 & 63.4 \\
\hline 1982 & 60.9 & 62.1 & 61.6 & 61.1 & 60.7 & 60.5 & 60.2 & 59.7 & 59.5 & 59.0 & 58.7 & 58.2 & 61.5 & 60.7 & 59.8 & 58.6 & 60.2 \\
\hline 1983 & 59.4 & 59.0 & 59.5 & 60.2 & 60.7 & 61.0 & 62.0 & 62.7 & 63.6 & 64.2 & 64.3 & 64.7 & 59.3 & 60.6 & 62.8 & 64.4 & 61.8 \\
\hline 1984 & 66.0 & 66.3 & 66.6 & 67.0 & 67.3 & 67.6 & 67.8 & 67.9 & 67.7 & 67.7 & 68.0 & 68.0 & 66.3 & 67.3 & 67.8 & 67.9 & 67.3 \\
\hline 1985 & 67.8 & 68.1 & 68.2 & 68.1 & 68.2 & 68.2 & 67.7 & 68.1 & 68.4 & 68.1 & 68.3 & 69.0 & 68.1 & 68.2 & 68.1 & 68.5 & 68.2 \\
\hline 1986 & 69.4 & 68.9 & 68.4 & 68.4 & 68.6 & 68.3 & 68.8 & 68.6 & 68.8 & 69.1 & 69.4 & 70.0 & 68.9 & 68.4 & 68.7 & 69.5 & 68.9 \\
\hline 1987 & 69.8 & 70.7 & 70.8 & 71.2 & 71.7 & 72.0 & 72.5 & 73.0 & 73.1 & 74.2 & 74.6 & 74.9 & 70.4 & 71.6 & 72.9 & 74.6 & 72.4 \\
\hline 1988 & 75.0 & 75.2 & 75.4 & 75.8 & 75.7 & 75.9 & 76.0 & 76.4 & 76.2 & 76.6 & 76.8 & 77.1 & 75.2 & 75.8 & 76.2 & 76.8 & 76.0 \\
\hline 1989 & 77.3 & 76.9 & 77.1 & 77.1 & 76.5 & 76.6 & 75.9 & 76.6 & 76.3 & 76.3 & 76.5 & 77.0 & 77.1 & 76.7 & 76.3 & 76.6 & 76.7 \\
\hline 1990 & 76.6 & 77.2 & 77.6 & 77.6 & 77.6 & 77.9 & 77.7 & 77.9 & 78.1 & 77.5 & 76.6 & 76.1 & 77.1 & 77.7 & 77.9 & 76.7 & 77.4 \\
\hline 1991 & 75.7 & 75.2 & 74.9 & 75.0 & 75.8 & 76.5 & 76.5 & 76.6 & 77.3 & 77.1 & 77.0 & 76.8 & 75.3 & 75.7 & 76.8 & 77.0 & 76.2 \\
\hline 1992 & 76.3 & 76.9 & 77.5 & 78.0 & 78.4 & 78.3 & 78.9 & 78.6 & 78.7 & 79.3 & 79.6 & 79.6 & 76.9 & 78.2 & 78.8 & 79.5 & 78.4 \\
\hline 1993. & 80.0 & 80.4 & 80.4 & 80.6 & 80.3 & 80.5 & 80.8 & 80.8 & 81.2 & 81.7 & 82.1 & 82.6 & 80.3 & 80.5 & 80.9 & 82.2 & 80.9 \\
\hline 1994. & 82.9 & 83.0 & 83.7 & 84.2 & 84.7 & 85.3 & 85.5 & 85.9 & 86.1 & 86.8 & 87.4 & 88.3 & 83.2 & 84.7 & 85.8 & 87.5 & 85.3 \\
\hline 1995 & 88.6 & 88.6 & 88.7 & 88.6 & 88.8 & 89.1 & 88.7 & 89.9 & 90.3 & 90.2 & 90.4 & 90.9 & 88.6 & 88.8 & 89.7 & 90.5 & 89.4 \\
\hline 1996 & 90.0 & 91.4 & 91.1 & 92.0 & 92.6 & 93.4 & 93.3 & 93.9 & 94.5 & 94.6 & 95.5 & 96.2 & 90.8 & 92.7 & 93.9 & 95.4 & 93.2 \\
\hline 1997 & 96.4 & 97.6 & 98.1 & 98.3 & 98.7 & 99.2 & 99.8 & 100.8 & 101.7 & 102.5 & 103.2 & 103.6 & 97.4 & 98.7 & 100.8 & 103.1 & 100.0 \\
\hline 1998 . & 104.1 & 104.2 & 104.5 & 105.2 & 105.7 & 105.3 & 105.1 & 107.0 & 106.7 & 107.5 & 107.3 & 107.5 & 104.3 & 105.4 & 106.3 & 107.4 & 105.8 \\
\hline 1999 & 108.2 & 108.6 & 109.0 & 109.3 & 110.0 & 110.0 & 110.7 & 111.4 & 111.0 & 112.3 & 112.8 & 113.9 & 108.6 & 109.8 & 111.0 & 113.0 & 110.6 \\
\hline 2000 & 113.8 & 114.3 & 114.9 & 115.7 & 116.4 & 116.4 & 115.9 & 115.5 & 115.9 & 115.4 & 115.2 & 115.0 & 114.3 & 116.2 & 115.8 & 115.2 & 115.4 \\
\hline 2001 . & 113.8 & 113.1 & 112.7 & 112.5 & 111.9 & 111.3 & 110.8 & 110.7 & 110.1 & 109.7 & 109.2 & 109.2 & 113.2 & 111.9 & 110.6 & 109.4 & 111.3 \\
\hline 2002 . & 109.9 & 109.7 & 110.3 & 110.7 & 111.0 & 111.8 & 111.7 & 111.6 & 111.6 & 111.1 & 111.2 & 110.7 & 110.0 & 111.2 & 111.6 & 111.0 & 111.0 \\
\hline 2003. & 110.9 & 111.0 & 110.6 & 109.5 & 109.6 & 109.9 & 110.6 & 110.5 & 111.3 & 111.6 & 112.7 & 112.9 & 110.8 & 109.7 & 110.8 & 112.4 & 110.9 \\
\hline 2004 & 113.2 & 114.4 & 114.1 & 114.7 & 115.5 & 115.1 & 115.9 & 116.0 & 115.7 & 116.6 & 116.8 & 117.8 & 113.9 & 115.1 & 115.9 & 117.1 & 115.5 \\
\hline
\end{tabular}

NoTE. Monthly percent change figures show the change from the previous month; quarterly figures show the change from the previous quarter at a compound annual rate of growth. Production and capacity indexes are expressed as percentages of output in 1997.
Estimates from October 2004 through December 2004 are subject to further revision in the upcoming monthly releases.

1. Annual averages of industrial production are calculated from not seasonally adjusted indexes. 
A.2. Revised data for capacity and utilization for total industry Seasonally adjusted data

\begin{tabular}{|c|c|c|c|c|c|c|c|c|c|c|c|c|c|c|c|c|c|}
\hline \multirow{2}{*}{ Year } & \multirow{2}{*}{ Jan. } & \multirow{2}{*}{ Feb. } & \multirow{2}{*}{ Mar. } & \multirow{2}{*}{ Apr. } & & & & & & & & & & $\mathrm{Qu}$ & rter & & \\
\hline & & & & & Vray & June & Jury & Aug. & sept. & Uct. & Nov. & DeC. & 1 & 2 & 3 & 4 & ayg \\
\hline & & & & & & & $\mathrm{Ca}$ & acity ( & rcent o & 997 ou & ut) & & & & & & \\
\hline 1972 & 60.7 & 60.8 & 60.9 & 61.1 & 61.2 & 61.4 & 61.5 & 61.7 & 61.8 & 62.0 & 62.2 & 62.4 & 60.8 & 61.2 & 61.7 & 62.2 & 61.5 \\
\hline 1973 & 62.6 & 62.7 & 62.9 & 63.1 & 63.3 & 63.6 & 63.8 & 64.0 & 64.2 & 64.4 & 64.6 & 64.8 & 62.7 & 63.3 & 64.0 & 64.6 & 63.7 \\
\hline 1974 & 65.0 & 65.2 & 65.4 & 65.5 & 65.7 & 65.9 & 66.0 & 66.2 & 66.4 & 66.5 & 66.6 & 66.8 & 65.2 & 65.7 & 66.2 & 66.6 & 65.9 \\
\hline 1975 & 66.9 & 67.0 & 67.1 & 67.3 & 67.4 & 67.5 & 67.6 & 67.7 & 67.9 & 68.0 & 68.1 & 68.2 & 67.0 & 67.4 & 67.7 & 68.1 & 67.6 \\
\hline 1976 & 68.4 & 68.5 & 68.7 & 68.8 & 69.0 & 69.1 & 69.2 & 69.4 & 69.5 & 69.7 & 69.9 & 70.0 & 68.5 & 69.0 & 69.4 & 69.9 & 69.2 \\
\hline 1977 & 70.2 & 70.3 & 70.5 & 70.7 & 70.8 & 71.0 & 71.2 & 71.4 & 71.6 & 71.8 & 72.0 & 72.2 & 70.3 & 70.8 & 71.4 & 72.0 & 71.2 \\
\hline 1978 & 72.4 & 72.6 & 72.8 & 73.0 & 73.2 & 73.4 & 73.6 & 73.8 & 74.0 & 74.2 & 74.4 & 74.6 & 72.6 & 73.2 & 73.8 & 74.4 & 73.5 \\
\hline 1979 & 74.7 & 74.9 & 75.1 & 75.2 & 75.4 & 75.6 & 75.7 & 75.9 & 76.1 & 76.2 & 76.4 & 76.5 & 74.9 & 75.4 & 75.9 & 76.4 & 75.6 \\
\hline 1980 & 76.6 & 76.8 & 76.9 & 77.1 & 77.2 & 77.4 & 77.5 & 77.6 & 77.8 & 77.9 & 78.1 & 78.3 & 76.8 & 77.2 & 77.6 & 78.1 & 77.4 \\
\hline 1981 & 78.4 & 78.6 & 78.8 & 78.9 & 79.1 & 79.3 & 79.5 & 79.7 & 79.9 & 80.1 & 80.3 & 80.5 & 78.6 & 79.1 & 79.7 & 80.3 & 79.4 \\
\hline 1982 & 80.7 & 80.8 & 81.0 & 81.2 & 81.4 & 81.5 & 81.7 & 81.8 & 82.0 & 82.1 & 82.2 & 82.3 & 80.8 & 81.4 & 81.8 & 82.2 & 81.6 \\
\hline 1983 & 82.3 & 82.4 & 82.5 & 82.5 & 82.6 & 82.6 & 82.6 & 82.7 & 82.7 & 82.8 & 82.9 & 82.9 & 82.4 & 82.6 & 82.7 & 82.9 & 82.6 \\
\hline 1984 & 83.0 & 83.1 & 83.2 & 83.3 & 83.5 & 83.6 & 83.7 & 83.9 & 84.1 & 84.2 & 84.4 & 84.6 & 83.1 & 83.5 & 83.9 & 84.4 & 83.7 \\
\hline 1985 & 84.8 & 84.9 & 85.1 & 85.3 & 85.5 & 85.7 & 85.9 & 86.0 & 86.2 & 86.4 & 86.5 & 86.7 & 84.9 & 85.5 & 86.0 & 86.5 & 85.7 \\
\hline 1986 & 86.8 & 86.9 & 87.0 & 87.1 & 87.2 & 87.4 & 87.5 & 87.6 & 87.7 & 87.8 & 87.9 & 88.1 & 86.9 & 87.2 & 87.6 & 87.9 & 87.4 \\
\hline 1987 & 88.2 & 88.3 & 88.5 & 88.6 & 88.8 & 89.0 & 89.1 & 89.2 & 89.4 & 89.5 & 89.6 & 89.7 & 88.3 & 88.8 & 89.2 & 89.6 & 89.0 \\
\hline 1988 & 89.8 & 89.9 & 89.9 & 90.0 & 90.1 & 90.1 & 90.2 & 90.3 & 90.3 & 90.4 & 90.5 & 90.6 & 89.9 & 90.1 & 90.3 & 90.5 & 90.2 \\
\hline 1989 & 90.8 & 90.9 & 91.0 & 91.2 & 91.4 & 91.6 & 91.7 & 91.9 & 92.1 & 92.3 & 92.5 & 92.7 & 90.9 & 91.4 & 91.9 & 92.5 & 91.7 \\
\hline 1990 & 92.9 & 93.1 & 93.3 & 93.5 & 93.7 & 93.9 & 94.0 & 94.2 & 94.4 & 94.5 & 94.7 & 94.8 & 93.1 & 93.7 & 94.2 & 94.7 & 93.9 \\
\hline 1991 & 94.9 & 95.1 & 95.2 & 95.3 & 95.5 & 95.6 & 95.7 & 95.9 & 96.0 & 96.1 & 96.3 & 96.4 & 95.1 & 95.5 & 95.9 & 96.3 & 95.7 \\
\hline 1992 & 96.5 & 96.7 & 96.9 & 97.1 & 97.3 & 97.5 & 97.7 & 97.9 & 98.0 & 98.2 & 98.4 & 98.6 & 96.7 & 97.3 & 97.9 & 98.4 & 97.6 \\
\hline 1993 & 98.7 & 98.9 & 99.0 & 99.2 & 99.3 & 99.5 & 99.6 & 99.8 & 99.9 & 100.1 & 100.3 & 100.5 & 98.9 & 99.3 & 99.8 & 100.3 & 99.6 \\
\hline 1994 & 100.7 & 100.9 & 101.1 & 101.4 & 101.7 & 102.0 & 102.3 & 102.6 & 102.9 & 103.3 & 103.6 & 104.0 & 100.9 & 101.7 & 102.6 & 103.6 & 102.2 \\
\hline 1995 & 104.4 & 104.8 & 105.2 & 105.7 & 106.1 & 106.5 & 107.0 & 107.5 & 108.0 & 108.4 & 108.9 & 109.4 & 104.8 & 106.1 & 107.5 & 108.9 & 106.8 \\
\hline 1996 & 109.9 & 110.4 & 111.0 & 111.5 & 112.0 & 112.5 & 113.0 & 113.5 & 114.0 & 114.5 & 115.0 & 115.5 & 110.5 & 112.0 & 113.5 & 115.0 & 112.7 \\
\hline 1997 & 116.1 & 116.6 & 117.2 & 117.7 & 118.3 & 118.9 & 119.6 & 120.2 & 120.9 & 121.7 & 122.4 & 123.1 & 116.6 & 118.3 & 120.3 & 122.4 & 119.4 \\
\hline 1998 & 123.9 & 124.6 & 125.4 & 126.1 & 126.8 & 127.6 & 128.2 & 128.9 & 129.5 & 130.1 & 130.6 & 131.2 & 124.6 & 126.8 & 128.8 & 130.6 & 127.7 \\
\hline 1999 & 131.7 & 132.3 & 132.8 & 133.3 & 133.8 & 134.4 & 134.9 & 135.4 & 135.9 & 136.4 & 136.9 & 137.4 & 132.3 & 133.8 & 135.4 & 136.9 & 134.6 \\
\hline 2000 & 138.0 & 138.5 & 139.0 & 139.5 & 140.0 & 140.5 & 141.0 & 141.4 & 141.9 & 142.3 & 142.8 & 143.2 & 138.5 & 140.0 & 141.4 & 142.7 & 140.7 \\
\hline 2001 & 143.6 & 143.9 & 144.3 & 144.6 & 145.0 & 145.3 & 145.6 & 145.9 & 146.1 & 146.4 & 146.6 & 146.8 & 143.9 & 145.0 & 145.9 & 146.6 & 145.3 \\
\hline 2002 & 147.0 & 147.2 & 147.3 & 147.4 & 147.5 & 147.5 & 147.5 & 147.5 & 147.4 & 147.4 & 147.3 & 147.2 & 147.2 & 147.5 & 147.5 & 147.3 & 147.4 \\
\hline 2003 & 147.1 & 147.0 & 146.9 & 146.9 & 146.8 & 146.8 & 146.7 & 146.8 & 146.8 & 146.9 & 146.9 & 147.0 & 147.0 & 146.8 & 146.8 & 146.9 & 146.9 \\
\hline 2004 & 147.2 & 147.3 & 147.5 & 147.6 & 147.8 & 147.9 & 148.1 & 148.2 & 148.4 & 148.5 & 148.7 & 148.8 & 147.3 & 147.8 & 148.2 & 148.7 & 148.0 \\
\hline & & & & & & & & & & & & & & & & & \\
\hline 1972 & 82.4 & 82.9 & 83.4 & 84.0 & 83.8 & 83.9 & 83.7 & 84.6 & 85.0 & 85.9 & 86.6 & 87.4 & 82.9 & 83.9 & 84.4 & 86.7 & 84.5 \\
\hline 1973 & 87.7 & 88.7 & 88.4 & 88.0 & 88.3 & 88.1 & 88.2 & 87.8 & 88.3 & 88.5 & 88.7 & 88.2 & 88.3 & 88.1 & 88.1 & 88.5 & 88.2 \\
\hline 1974 & 87.3 & 86.8 & 86.5 & 86.1 & 86.4 & 86.1 & 85.9 & 84.9 & 84.8 & 84.3 & 81.4 & 78.3 & 86.8 & 86.2 & 85.2 & 81.3 & 84.9 \\
\hline 1975 & 77.2 & 75.1 & 74.2 & 74.1 & 73.9 & 74.2 & 74.9 & 75.5 & 76.3 & 76.4 & 76.5 & 77.3 & 75.5 & 74.0 & 75.5 & 76.7 & 75.5 \\
\hline 1976 & 78.2 & 78.8 & 78.6 & 79.1 & 79.2 & 79.0 & 79.3 & 79.7 & 79.7 & 79.6 & 80.7 & 81.3 & 78.6 & 79.1 & 79.6 & 80.5 & 79.4 \\
\hline 1977 & 80.7 & 81.7 & 82.5 & 83.0 & 83.5 & 83.8 & 83.8 & 83.7 & 83.9 & 83.9 & 83.8 & 83.6 & 81.6 & 83.4 & 83.8 & 83.8 & 83.2 \\
\hline 1978 & 82.2 & 82.4 & 83.7 & 85.1 & 85.2 & 85.5 & 85.2 & 85.3 & 85.3 & 85.9 & 86.3 & 86.6 & 82.7 & 85.2 & 85.3 & 86.3 & 84.9 \\
\hline 1979 & 85.8 & 86.1 & 86.2 & 85.1 & 85.5 & 85.3 & 85.0 & 84.2 & 84.2 & 84.4 & 84.2 & 84.1 & 86.0 & 85.3 & 84.5 & 84.2 & 85.0 \\
\hline 1980 & 84.3 & 84.2 & 83.8 & 81.9 & 79.7 & 78.6 & 77.9 & 78.0 & 79.2 & 80.0 & 81.1 & 81.4 & 84.1 & 80.1 & 78.4 & 80.8 & 80.9 \\
\hline 1981 & 80.8 & 80.3 & 80.5 & 80.0 & 80.3 & 80.5 & 80.9 & 80.7 & 80.0 & 79.2 & 78.2 & 77.2 & 80.5 & 80.3 & 80.5 & 78.2 & 79.9 \\
\hline 1982 & 75.5 & 76.8 & 76.0 & 75.2 & 74.6 & 74.1 & 73.7 & 73.0 & 72.6 & 71.9 & 71.5 & 70.8 & 76.1 & 74.6 & 73.1 & 71.4 & 73.8 \\
\hline 1983 & 72.1 & 71.6 & 72.1 & 73.0 & 73.5 & 73.9 & 75.0 & 75.8 & 76.9 & 77.5 & 77.7 & 78.0 & 71.9 & 73.4 & 75.9 & 77.7 & 74.7 \\
\hline 1984 & 79.5 & 79.8 & 80.1 & 80.4 & 80.7 & 80.9 & 81.0 & 80.9 & 80.6 & 80.4 & 80.5 & 80.4 & 79.8 & 80.7 & 80.8 & 80.4 & 80.4 \\
\hline 1985 & 80.0 & 80.2 & 80.2 & 79.9 & 79.7 & 79.6 & 78.9 & 79.1 & 79.3 & 78.9 & 79.0 & 79.7 & 80.1 & 79.7 & 79.1 & 79.2 & 79.5 \\
\hline 1986 & 80.0 & 79.2 & 78.6 & 78.5 & 78.6 & 78.2 & 78.6 & 78.4 & 78.4 & 78.7 & 78.9 & 79.5 & 79.3 & 78.5 & 78.5 & 79.0 & 78.8 \\
\hline 1987 & 79.1 & 80.0 & 80.0 & 80.3 & 80.7 & 81.0 & 81.3 & 81.8 & 81.8 & 82.9 & 83.3 & 83.5 & 79.7 & 80.7 & 81.6 & 83.2 & 81.3 \\
\hline 1988 & 83.5 & 83.7 & 83.9 & 84.2 & 84.1 & 84.2 & 84.3 & 84.7 & 84.4 & 84.8 & 84.8 & 85.1 & 83.7 & 84.2 & 84.5 & 84.9 & 84.3 \\
\hline 1989 & 85.1 & 84.6 & 84.7 & 84.5 & 83.8 & 83.6 & 82.7 & 83.3 & 82.9 & 82.7 & 82.7 & 83.1 & 84.8 & 84.0 & 82.9 & 82.8 & 83.6 \\
\hline 1990 & 82.4 & 83.0 & 83.2 & 83.0 & 82.9 & 83.0 & 82.7 & 82.7 & 82.8 & 82.0 & 80.9 & 80.2 & 82.9 & 82.9 & 82.7 & 81.1 & 82.4 \\
\hline 1991 & 79.7 & 79.1 & 78.6 & 78.6 & 79.4 & 80.0 & 79.9 & 79.9 & 80.5 & 80.2 & 80.0 & 79.6 & 79.2 & 79.4 & 80.1 & 79.9 & 79.6 \\
\hline 1992 & 79.1 & 79.5 & 80.0 & 80.4 & 80.6 & 80.4 & 80.8 & 80.3 & 80.3 & 80.7 & 80.9 & 80.8 & 79.5 & 80.4 & 80.5 & 80.8 & 80.3 \\
\hline 1993 & 81.1 & 81.3 & 81.1 & 81.3 & 80.9 & 80.9 & 81.1 & 81.0 & 81.2 & 81.7 & 81.9 & 82.2 & 81.2 & 81.0 & 81.1 & 81.9 & 81.3 \\
\hline 1994 & 82.4 & 82.2 & 82.8 & 83.0 & 83.3 & 83.6 & 83.6 & 83.7 & 83.6 & 84.1 & 84.3 & 84.9 & 82.5 & 83.3 & 83.6 & 84.4 & 83.5 \\
\hline 1995 & 84.8 & 84.5 & 84.3 & 83.9 & 83.7 & 83.6 & 82.9 & 83.7 & 83.7 & 83.2 & 83.0 & 83.0 & 84.5 & 83.7 & 83.4 & 83.0 & 83.7 \\
\hline 1996 & 81.9 & 82.7 & 82.1 & 82.5 & 82.7 & 83.1 & 82.6 & 82.8 & 82.9 & 82.6 & 83.0 & 83.2 & 82.2 & 82.8 & 82.8 & 82.9 & 82.7 \\
\hline 1997 & 83.1 & 83.7 & 83.7 & 83.5 & 83.4 & 83.4 & 83.5 & 83.8 & 84.1 & 84.3 & 84.3 & 84.1 & 83.5 & 83.4 & 83.8 & 84.2 & 83.7 \\
\hline 1998 & 84.0 & 83.6 & 83.3 & 83.4 & 83.3 & 82.5 & 81.9 & 83.1 & 82.4 & 82.7 & 82.1 & 82.0 & 83.7 & 83.1 & 82.5 & 82.3 & 82.9 \\
\hline 1999 & 82.1 & 82.1 & 82.1 & 81.9 & 82.2 & 81.9 & 82.1 & 82.3 & 81.7 & 82.3 & 82.4 & 82.9 & 82.1 & 82.0 & 82.0 & 82.5 & 82.2 \\
\hline 2000 & 82.5 & 82.5 & 82.7 & 82.9 & 83.2 & 82.9 & 82.2 & 81.7 & 81.7 & 81.1 & 80.7 & 80.3 & 82.6 & 83.0 & 81.9 & 80.7 & 82.0 \\
\hline 2001 & 79.3 & 78.6 & 78.1 & 77.8 & 77.2 & 76.6 & 76.1 & 75.9 & 75.4 & 75.0 & 74.5 & 74.4 & 78.7 & 77.2 & 75.8 & 74.6 & 76.6 \\
\hline 2002 & 74.8 & 74.6 & 74.9 & 75.1 & 75.3 & 75.8 & 75.7 & 75.7 & 75.7 & 75.4 & 75.5 & 75.2 & 74.7 & 75.4 & 75.7 & 75.4 & 75.3 \\
\hline 2003 & 75.4 & 75.5 & 75.2 & 74.6 & 74.7 & 74.9 & 75.4 & 75.3 & 75.8 & 76.0 & 76.7 & 76.8 & 75.4 & 74.7 & 75.5 & 76.5 & 75.5 \\
\hline 2004 & 76.9 & 77.7 & 77.4 & 77.7 & 78.2 & 77.8 & 78.3 & 78.3 & 78.0 & 78.5 & 78.6 & 79.2 & 77.3 & 77.9 & 78.2 & 78.8 & 78.0 \\
\hline
\end{tabular}

Note. See also general note to table A.1. 
A.3. Rates of change in industrial production, by market and industry group, 2000-2004 ${ }^{1}$

\begin{tabular}{|c|c|c|c|c|c|c|c|c|c|c|c|}
\hline \multirow[t]{2}{*}{ Item } & \multirow{2}{*}{$\begin{array}{l}\text { NAICS } \\
\text { code }^{2}\end{array}$} & \multicolumn{5}{|c|}{$\begin{array}{l}\text { Revised rate of change } \\
\text { (percent) }\end{array}$} & \multicolumn{5}{|c|}{$\begin{array}{l}\text { Difference between rates of change: } \\
\text { revised minus earlier } \\
\text { (percentage points) }\end{array}$} \\
\hline & & 2000 & 2001 & 2002 & 2003 & 2004 & 2000 & 2001 & 2002 & 2003 & $2004^{3}$ \\
\hline Total industry & $\cdots$ & 1.9 & -5.1 & 1.5 & 1.2 & 4.2 & -.4 & .2 & .1 & -.3 & -.7 \\
\hline \multicolumn{12}{|l|}{ MARKET GRouP } \\
\hline Final products and nonindustrial supplies .. & $\cdots$ & 2.0 & -4.7 & .6 & 1.7 & 4.5 & -.4 & .3 & .1 & .5 & -.7 \\
\hline Consumer goods & $\ldots$ & .9 & -1.5 & 1.6 & 1.3 & 2.7 & -.1 & .7 & 6 & .8 & -.6 \\
\hline Durable $\ldots \ldots \ldots \ldots \ldots$ & $\ldots$ & -2.1 & -1.3 & 6.4 & 3.3 & 1.6 & -.2 & 1.6 & .4 & .3 & -.7 \\
\hline Automotive products . & $\ldots$ & -4.5 & 2.3 & 10.1 & 5.2 & 1.3 & .5 & 1.2 & .2 & .3 & -2.3 \\
\hline Home electronics $\ldots \ldots \ldots \ldots$ & $\cdots$ & 13.7 & 5.8 & -4.0 & 34.8 & -7.7 & -2.0 & 16.1 & -8.4 & 9.8 & -2.2 \\
\hline Appliances, furniture, carpeting .... & $\ldots$ & -.9 & -3.4 & 1.8 & 1.4 & 2.8 & -.3 & -1.4 & .0 & .4 & 2.6 \\
\hline Miscellaneous goods .............. & $\ldots$ & -1.5 & -6.6 & 4.3 & -3.5 & 3.0 & -1.2 & 1.5 & 1.9 & -1.3 & .8 \\
\hline Nondurable.........$\ldots \ldots$ & $\ldots$ & 2.0 & -1.6 & -.2 & 4 & 3.1 & .0 & .3 & .5 & .8 & -.5 \\
\hline Non-energy $\ldots \ldots \ldots \ldots$ & $\ldots$ & .8 & -.8 & -2.3 & 8 & 3.9 & -.2 & .3 & .5 & .8 & -.8 \\
\hline Foods and tobacco & $\cdots$ & 1.2 & -1.2 & -3.6 & 2.4 & 4.1 & .5 & -.6 & .2 & 4.0 & 1.3 \\
\hline Clothing .............. & $\ldots$ & -7.7 & -20.8 & -9.7 & -14.9 & -4.8 & -2.2 & -5.6 & -7.3 & -1.7 & -2.6 \\
\hline Chemical products ... & $\ldots$ & 3.8 & 7.0 & .9 & 6 & 3.6 & -.6 & 4.0 & 2.7 & -2.9 & -3.0 \\
\hline Paper products .......... & $\ldots$ & -2.0 & -2.7 & -8 & .6 & 6.3 & -.9 & .6 & .1 & -4.9 & -4.3 \\
\hline Energy $\ldots \ldots \ldots \ldots \ldots \ldots \ldots$ & $\ldots$ & 7.9 & -5.2 & 10.1 & -1.4 & -.3 & .8 & 6 & 1.3 & .6 & .4 \\
\hline Business equipment & $\ldots$ & 6.2 & -13.3 & -2.6 & 4.7 & 9.9 & -.6 & -.5 & -1.2 & 1.9 & -1.3 \\
\hline Transit $\ldots \ldots \ldots \ldots$ & $\cdots$ & -11.7 & -3.5 & -12.6 & .2 & 11.6 & -.5 & 2.5 & 2.5 & 3.5 & 2.4 \\
\hline Information processing $\ldots \ldots \ldots$ & $\ldots$ & 19.8 & -17.4 & -3.7 & 16.3 & 10.1 & .6 & -4.6 & -9.2 & 7.9 & -4.0 \\
\hline Industrial and other $\ldots \ldots \ldots$ & $\ldots$ & 3.6 & -13.7 & 2.1 & -.5 & 9.3 & -1.3 & 1.4 & 3.0 & -1.8 & -.8 \\
\hline Defense and space equipment & $\cdots$ & -4.3 & 8.0 & 3.8 & 5.3 & 6.9 & -1.3 & -4.4 & .2 & .7 & -.4 \\
\hline Construction supplies ... & $\ldots$ & -1.1 & -5.0 & .1 & .6 & 4.3 & -.9 & 1.5 & -.4 & -.5 & 1.5 \\
\hline Business supplies $\ldots \ldots \ldots \ldots \ldots$ & $\cdots$ & 2.3 & -5.5 & 1.4 & .0 & 4.3 & -.6 & .1 & .1 & -1.4 & -2.1 \\
\hline Materials ...... & $\ldots$ & 1.9 & -5.6 & 2.8 & .5 & 3.7 & -.4 & .1 & .2 & -1.4 & -.7 \\
\hline Non-energy & $\ldots$ & 1.8 & -6.5 & 3.5 & .8 & 5.3 & -.6 & .1 & .5 & -1.6 & -.9 \\
\hline Durable ............ & $\ldots$ & 4.9 & -7.2 & 4.6 & 2.2 & 6.9 & -.7 & -.1 & .3 & -2.0 & -.9 \\
\hline Consumer parts ... & $\cdots$ & -8.5 & -7.9 & 7.1 & 2.7 & 2.1 & -1.4 & -.8 & .4 & .7 & .1 \\
\hline Equipment parts $\ldots \ldots \ldots \ldots$ & $\cdots$ & 22.2 & -7.9 & 6.2 & 5.8 & 15.7 & -8 & -.5 & .3 & -5.9 & .1 \\
\hline Other ............. & $\ldots$ & -4.3 & -6.2 & 1.9 & -.9 & 2.7 & -.4 & .6 & .4 & -.4 & -1.6 \\
\hline Nondurable & $\cdots$ & -3.9 & -5.2 & 1.7 & -1.3 & 2.6 & -.2 & .4 & .8 & -.8 & -.8 \\
\hline Textile & $\ldots$ & -10.2 & -9.5 & 2.0 & -13.0 & -5.1 & -.4 & 2.2 & 3.0 & -2.7 & 1.5 \\
\hline Paper .... & $\ldots$ & -4.1 & -6.3 & 2.1 & -4.3 & 3.2 & .6 & -.2 & .6 & .2 & -1.0 \\
\hline Chemical & $\ldots$ & -4.4 & -4.6 & 2.1 & 2.0 & 4.2 & -.5 & .5 & .4 & -.7 & -.9 \\
\hline Energy $\ldots \ldots \ldots$ & $\ldots$ & 1.9 & -2.8 & .4 & -.3 & -.4 & .2 & .0 & -.6 & -.8 & -.1 \\
\hline \multicolumn{12}{|l|}{ INDUSTRY GROUP } \\
\hline Manufacturing $^{4} \ldots \ldots \ldots \ldots$ & & 1.5 & -5.4 & 1.3 & 1.5 & 5.0 & -.5 & .2 & .2 & -.3 & -.9 \\
\hline Manufacturing (NAICS) .. & $31-33$ & 1.7 & -5.3 & 1.6 & 1.6 & 5.0 & -.5 & .2 & .3 & -.1 & -.7 \\
\hline Durable manufacturing ... & & 4.1 & -7.2 & 3.2 & 3.3 & 6.7 & -.7 & .1 & .2 & -.4 & -.8 \\
\hline Wood products $\ldots \ldots \ldots \ldots \ldots$ & 321 & -6.9 & -1.6 & .0 & 3.2 & .5 & -.4 & 6 & 1.8 & -.6 & -1.1 \\
\hline Nonmetallic mineral products & 327 & -3.4 & -2.5 & .3 & 1.7 & 4.3 & -1.8 & 3.1 & -1.8 & .5 & 3.9 \\
\hline Primary metal $\ldots \ldots \ldots \ldots \ldots$ & 331 & -10.2 & -8.7 & 7.1 & .6 & 4.8 & -1.0 & 2.0 & 3.6 & 1.2 & -2.8 \\
\hline Fabricated metal products .... & 332 & .0 & -8.6 & -.2 & -2.9 & 3.2 & .0 & -.2 & -.1 & -1.1 & -1.0 \\
\hline Machinery $\ldots \ldots \ldots \ldots \ldots \ldots$ & 333 & 1.8 & -16.7 & 1.3 & .6 & 12.2 & -.6 & .3 & 2.2 & -2.2 & -.6 \\
\hline Computer and electronic products & 334 & 29.0 & -9.0 & 5.6 & 14.5 & 14.9 & -.4 & -1.4 & -5.2 & -1.2 & -.9 \\
\hline $\begin{array}{l}\text { Electrical equipment, appliances, } \\
\text { and components } \ldots \ldots \ldots \ldots \ldots\end{array}$ & 335 & 2.5 & -14.7 & -5.2 & 1.1 & 4.7 & .2 & -1.9 & -3.0 & .0 & -.7 \\
\hline Motor vehicles and parts $\ldots \ldots \ldots$ & $3361-3$ & -9.7 & -2.1 & 11.3 & $\begin{array}{l}1.1 \\
4.8\end{array}$ & 2.5 & -.6 & $\begin{array}{r}-1.9 \\
.7\end{array}$ & $\begin{array}{r}-5.0 \\
1.4\end{array}$ & $\begin{array}{l}.0 \\
1.0\end{array}$ & -.9 \\
\hline Aerospace and miscellaneous & & & & & & & & & & & \\
\hline transportation equipment & $3364-9$ & -4.8 & 4.7 & -7.5 & .8 & 5.8 & -.9 & -.2 & 2.3 & .3 & -.4 \\
\hline Furniture and related products & 337 & -.7 & -6.3 & 4.2 & -1.8 & 2.0 & -1.3 & 1.2 & 4.6 & .9 & -.7 \\
\hline Miscellaneous ............. & 339 & 2.9 & -1.5 & 7.4 & -2.2 & 4.5 & -3.2 & 1.3 & 3.8 & -1.0 & -.9 \\
\hline Nondurable manufacturing $\ldots$. & $\ldots$ & -1.5 & -2.9 & -.4 & -.4 & 2.9 & -.1 & .3 & .5 & .3 & -.6 \\
\hline Food, beverage, and tobacco & & & & & & & & & & & \\
\hline products $\ldots \ldots \ldots \ldots \ldots$ & 311,2 & 1.0 & -.8 & -2.9 & 2.1 & 3.6 & .5 & -.4 & .7 & 3.3 & .7 \\
\hline Textile and product mills & 313,4 & -6.7 & -9.5 & .4 & -8.5 & -2.5 & -.3 & .7 & 1.7 & -1.6 & 1.6 \\
\hline Apparel and leather ...... & 315,6 & -7.5 & -21.0 & -9.3 & -14.3 & -4.3 & -2.1 & -5.6 & -7.3 & -1.9 & -2.6 \\
\hline Paper $\ldots \ldots \ldots \ldots$ & 322 & -4.7 & -5.7 & 4.1 & -3.3 & 3.7 & .1 & .3 & 1.2 & -6 & .1 \\
\hline Printing and support $\ldots \ldots \ldots$ & 323 & -1.3 & -8.1 & -3.2 & -3.5 & .8 & .0 & -1.4 & -1.5 & 2.0 & -3.9 \\
\hline Petroleum and coal products.. & 324 & -1.1 & .8 & 4.1 & 1.2 & 3.9 & .6 & 3.3 & 2.9 & -1.3 & 3.4 \\
\hline Chemical ................. & 325 & -.6 & .2 & 1.0 & 1.2 & 3.7 & -.4 & 1.5 & 1.1 & -1.8 & -2.6 \\
\hline Plastics and rubber products . & 326 & -4.0 & -4.4 & 2.4 & -2.2 & 1.6 & -.8 & 1.3 & .2 & -1.8 & -.8 \\
\hline Other manufacturing (non-NAICS) & 1133,5111 & -1.9 & -6.3 & -3.9 & .3 & 4.6 & -.4 & .0 & -1.7 & -4.0 & -3.6 \\
\hline Mining . & 21 & 1.3 & -.6 & -3.8 & .2 & -1.5 & .3 & .4 & -1.5 & -.1 & .6 \\
\hline Utilities ... & 2211,2 & 6.1 & -5.1 & 7.1 & -.6 & 2.3 & .0 & .1 & .5 & .0 & .0 \\
\hline Electric .... & 2211 & 4.9 & -3.7 & 5.7 & .5 & 3.5 & .0 & .0 & .2 & -.1 & .4 \\
\hline Natural gas & 2212 & 13.2 & -12.8 & 15.4 & -6.2 & -3.6 & .3 & .0 & 2.0 & -.3 & -1.9 \\
\hline
\end{tabular}

NoTE. Estimates for the fourth quarter of 2004 are subject to further revision in the upcoming monthly releases.

1. Rates of change are calculated as the percent change in the seasonally adjusted index from the fourth quarter of the previous year to the fourth quarter of the year specified in the column heading.

2. North American Industry Classification System.

3. For 2004, the calculation of "revised minus earlier" is based on annualized rates of change from the fourth quarter of 2003 to the third quarter of 2004 .

4. Manufacturing comprises those industries included in the NAICS definition of manufacturing plus those industries-newspaper, periodical, book, and directory publishing and logging - that have traditionally been considered to be a part of manufacturing and are included in the industrial sector.

. Not applicable. 
A.4. Rates of change in industrial production, special aggregates and selected detail, 2000-2004 ${ }^{1}$

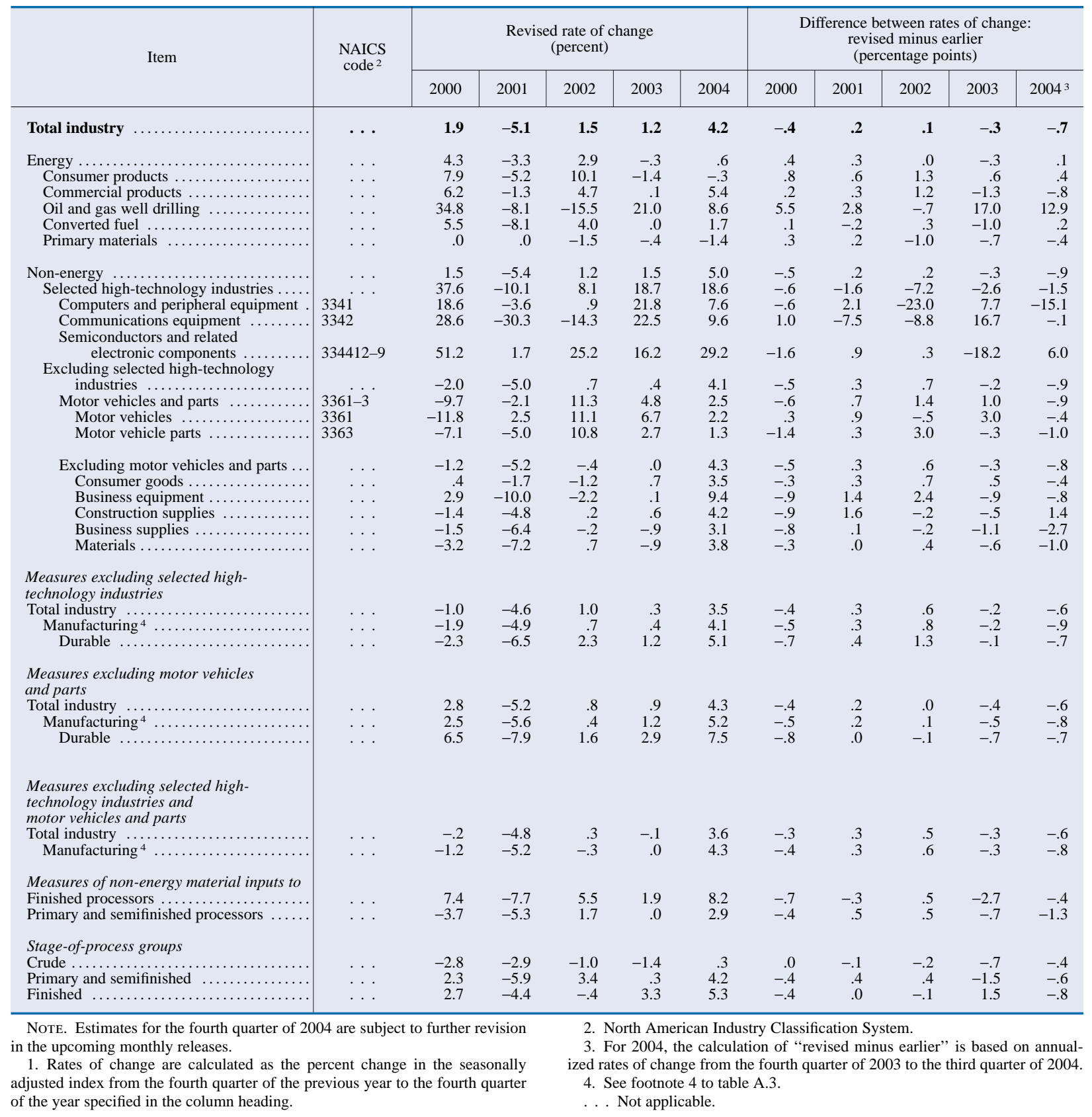


A.5. Capacity utilization rates, by industry group, 1972-20041

\begin{tabular}{|c|c|c|c|c|c|c|c|c|c|c|}
\hline \multirow{2}{*}{ Item } & \multirow{2}{*}{$\begin{array}{l}\text { NAICS } \\
\operatorname{code}^{2}\end{array}$} & \multicolumn{6}{|c|}{$\begin{array}{c}\text { Revised rate } \\
\text { (percent of capacity, seasonally adjusted) }\end{array}$} & \multicolumn{3}{|c|}{$\begin{array}{l}\text { Difference between rates: } \\
\text { revised minus earlier } \\
\text { (percentage points) }\end{array}$} \\
\hline & & $\begin{array}{l}\text { 1972-2003 } \\
\text { avg. }\end{array}$ & $\begin{array}{l}\text { 1988-89 } \\
\text { high }\end{array}$ & $\begin{array}{l}\text { 1990-91 } \\
\text { low }\end{array}$ & 2002:Q4 & 2003:Q4 & 2004:Q4 & 2002:Q4 & 2003:Q4 & 2004:Q3 ${ }^{3}$ \\
\hline Total industry & $\cdots$ & 81.1 & 85.1 & 78.6 & 75.4 & 76.5 & 78.8 & .2 & 1.0 & .9 \\
\hline Manufacturing $^{4} \quad \ldots \ldots \ldots$ & & 79.9 & 85.6 & 77.2 & 73.5 & 74.8 & 77.6 & .1 & 6 & .4 \\
\hline Manufacturing (NAICS) .. & $31-33$ & 79.7 & 85.5 & 77.0 & 73.2 & 74.3 & 77.1 & .0 & .7 & .7 \\
\hline Durable manufacturing & & 78.1 & 84.5 & 73.4 & 70.7 & 72.1 & 75.2 & .2 & .7 & 1.0 \\
\hline Wood products $\ldots \ldots \ldots \ldots$ & 321 & 80.1 & 88.9 & 73.1 & 74.4 & 77.4 & 78.2 & .9 & .8 & .6 \\
\hline Nonmetallic mineral products & 327 & 79.2 & 84.9 & 72.0 & 76.8 & 78.0 & 80.7 & -1.1 & -.8 & 1.4 \\
\hline Primary metal $\ldots \ldots \ldots \ldots \ldots$ & 331 & 80.5 & 94.3 & 74.6 & 78.6 & 79.3 & 83.8 & 1.4 & 2.8 & .7 \\
\hline Fabricated metal products & 332 & 76.9 & 80.2 & 71.6 & 69.4 & 67.7 & 70.0 & -.3 & -.4 & -.1 \\
\hline Machinery $\ldots \ldots \ldots \ldots \ldots$ & 333 & 78.9 & 84.8 & 73.0 & 67.9 & 69.9 & 78.6 & 1.1 & .6 & .5 \\
\hline Computer and electronic products & 334 & 79.0 & 81.7 & 76.6 & 62.7 & 67.7 & 71.0 & -.4 & .9 & 2.4 \\
\hline $\begin{array}{l}\text { Electrical equipment, appliances, } \\
\text { and components } \ldots \ldots \ldots \ldots \ldots\end{array}$ & 335 & 82.8 & 87.5 & 75.1 & 72.6 & 74.8 & 79.3 & -1.5 & -.8 & -.5 \\
\hline Motor vehicles and parts ........... & $3361-3$ & 77.6 & 90.3 & 56.0 & 80.9 & 81.9 & 82.2 & -.3 & .1 & .2 \\
\hline Aerospace and miscellaneous & & & & & 80.5 & & & & .1 & \\
\hline transportation equipment & $3364-9$ & 72.7 & 88.7 & 82.1 & 63.2 & 63.2 & 66.4 & -1.1 & -1.5 & -2.1 \\
\hline Furniture and related products & 337 & 78.8 & 83.6 & 69.4 & 72.6 & 71.1 & 73.3 & 1.5 & 1.9 & 2.2 \\
\hline Miscellaneous ................ & 339 & 76.5 & 81.7 & 77.7 & 75.9 & 74.1 & 77.4 & -.8 & -1.6 & -2.4 \\
\hline Nondurable manufacturing $\ldots \ldots \ldots \ldots$ & & 81.9 & 87.1 & 81.7 & 76.6 & 77.3 & 79.7 & -.2 & .5 & .0 \\
\hline Food, beverage, and tobacco products & 311,2 & 81.9 & 85.6 & 81.0 & 76.6 & 78.7 & 81.4 & -.7 & 1.7 & 1.4 \\
\hline Textile and product mills $\ldots \ldots \ldots \ldots$ & 313,4 & 83.4 & 91.5 & 77.2 & 76.8 & 73.4 & 74.6 & 1.9 & 1.3 & 2.5 \\
\hline Apparel and leather ........... & 315,6 & 79.6 & 84.2 & 77.3 & 66.7 & 64.9 & 70.8 & -.4 & .8 & 2.2 \\
\hline Paper ............. & 322 & 88.2 & 93.7 & 85.2 & 84.8 & 83.5 & 86.9 & -.1 & -.1 & -.3 \\
\hline Printing and support $\ldots \ldots \ldots$ & 323 & 84.1 & 91.6 & 82.7 & 73.0 & 71.7 & 72.1 & -1.3 & .5 & -2.8 \\
\hline Petroleum and coal products & 324 & 86.0 & 88.9 & 82.9 & 87.0 & 88.9 & 91.2 & -1.1 & -.2 & 1.2 \\
\hline Chemical $\ldots . \ldots \ldots \ldots \ldots \ldots$ & 325 & 78.5 & 85.7 & 80.9 & 73.5 & 74.1 & 76.2 & .6 & -.2 & -1.1 \\
\hline Plastics and rubber products ..... & 326 & 83.7 & 91.1 & 77.1 & 81.1 & 81.2 & 83.4 & 1.5 & .3 & .1 \\
\hline Other manufacturing (non-NAICS) & 1133,5111 & 84.8 & 90.5 & 80.4 & 80.7 & 83.3 & 87.0 & 1.8 & -.1 & -2.8 \\
\hline Mining . & 21 & 87.1 & 85.8 & 83.5 & 85.4 & 87.1 & 86.1 & .8 & 1.8 & 2.4 \\
\hline Utilities & 2211,2 & 86.9 & 92.8 & 84.2 & 87.9 & 84.8 & 85.1 & .7 & 1.7 & 1.7 \\
\hline Selected high-technology industries .... & & 78.6 & 81.0 & 74.3 & 60.9 & 66.7 & 69.7 & -.9 & -.3 & 1.8 \\
\hline Computers and peripheral equipment & 3341 & 78.6 & 80.2 & 67.5 & 70.9 & 74.1 & 76.4 & -.7 & .7 & -.7 \\
\hline Communications equipment $\ldots . \ldots \ldots$ & 3342 & 76.6 & 80.8 & 73.4 & 42.8 & 52.8 & 58.8 & -5.4 & 2.1 & 2.7 \\
\hline $\begin{array}{l}\text { Semiconductors and related electronic } \\
\text { components } \ldots \ldots \ldots \ldots \ldots \ldots \ldots \ldots\end{array}$ & $334412-9$ & 81.2 & 82.8 & 77.5 & 69.8 & 74.8 & 75.2 & 3.2 & -.7 & 4.3 \\
\hline $\begin{array}{l}\text { Measures excluding selected } \\
\text { high-technology industries }\end{array}$ & & & & & & & & & & \\
\hline Total industry...$\ldots \ldots \ldots \ldots$ & $\ldots$ & 81.2 & 85.5 & 78.8 & 76.4 & 77.1 & 79.6 & .1 & 6 & .3 \\
\hline Manufacturing ${ }^{4} \ldots \ldots \ldots$ & $\ldots$ & 80.0 & 86.0 & 77.3 & 74.6 & 75.4 & 78.4 & .0 & .2 & -.2 \\
\hline Stage-of-process groups & & & & & & & & & & \\
\hline Crude..$\ldots \ldots \ldots \ldots \ldots$ & $\cdots$ & 86.4 & 88.9 & 84.8 & 83.5 & 84.9 & 85.6 & .4 & 1.1 & 1.2 \\
\hline Primary and semifinished $\ldots$ & $\ldots$ & 82.2 & 86.5 & 77.5 & 78.0 & 78.4 & 80.1 & .5 & .8 & .7 \\
\hline Finished $\ldots \ldots \ldots \ldots \ldots \ldots \ldots \ldots$ & $\cdots$ & 78.0 & 83.1 & 77.2 & 70.8 & 72.4 & 75.9 & -.3 & .8 & .6 \\
\hline $\begin{array}{l}\text { Note. Estimates for the fourth quarter of } 2004 \\
\text { the upcoming monthly releases. } \\
\text { 1. See footnote } 1 \text { to table A.3. } \\
\text { 2. North American Industry Classification Syste }\end{array}$ & are subject to & further re & & $\begin{array}{l}\text { 3. See } f \\
\text { 4. See } f \\
\text {. . No }\end{array}$ & $\begin{array}{l}\text { otnote } 3 \text { to } \\
\text { otnote } 4 \text { to } \\
\text { applicable }\end{array}$ & $\begin{array}{l}\text { able A.3. } \\
\text { able A.3. }\end{array}$ & & & & \\
\hline
\end{tabular}


A.6. Rates of change in capacity, by industry group, 2000-2004 ${ }^{1}$

\begin{tabular}{|c|c|c|c|c|c|c|c|c|c|c|}
\hline \multirow[t]{2}{*}{ Industry group } & \multicolumn{5}{|c|}{$\begin{array}{l}\text { Revised rate of change } \\
\text { (percent) }\end{array}$} & \multicolumn{5}{|c|}{$\begin{array}{l}\text { Difference between rates of change: } \\
\text { revised minus earlier } \\
\text { (percentage points) }\end{array}$} \\
\hline & 2000 & 2001 & 2002 & 2003 & 2004 & 2000 & 2001 & 2002 & 2003 & 2004 \\
\hline Total industry ... & 4.3 & 2.7 & .5 & -.2 & 1.2 & .2 & .4 & -1.2 & -1.3 & -.4 \\
\hline Manufacturing $^{2} \ldots \ldots \ldots$ & 5.0 & 2.6 & .0 & -.1 & 1.1 & .1 & .4 & -1.1 & -1.1 & -.5 \\
\hline Manufacturing (NAICS) & 5.3 & 2.8 & .2 & .1 & 1.2 & .1 & 4 & -1.1 & -1.0 & -.6 \\
\hline Durable ............. & 8.5 & 4.9 & .7 & 1.3 & 2.2 & .2 & .2 & -2.0 & -1.2 & -1.4 \\
\hline Nondurable $\ldots \ldots \ldots \ldots \ldots \ldots$ & 1.0 & .2 & -.5 & -1.3 & -.2 & .1 & .6 & -.1 & -.6 & .3 \\
\hline Other manufacturing (non-NAICS) & .7 & -1.3 & -2.5 & -2.9 & .1 & 1.0 & -.3 & -.9 & -1.5 & .7 \\
\hline Mining $\ldots \ldots \ldots \ldots \ldots \ldots \ldots \ldots$ & -1.0 & 2.0 & -.6 & -1.7 & -.4 & .2 & -.7 & -.9 & -1.2 & -.4 \\
\hline Utilities ....................... & 3.2 & 3.9 & 4.6 & 3.0 & 1.9 & .7 & .2 & -1.4 & -1.3 & .4 \\
\hline Selected high-technology industries & 38.8 & 27.4 & 8.0 & 8.4 & 13.4 & -3.4 & 2.5 & -9.7 & -3.4 & -7.3 \\
\hline Manufacturing except selected & 17 & - & 4 & . & (5) & - & 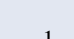 & & & - \\
\hline 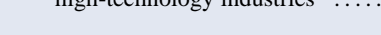 & 1.1 & .5 & -.4 & -.0 & .1 & .4 & .1 & -.2 & -.4 & -.1 \\
\hline Stage-of-process groups & & & & & & & & & & \\
\hline Crude ................. & -.9 & .9 & -.8 & -2.2 & -.2 & .4 & -.3 & -.4 & -1.1 & -.1 \\
\hline Primary and semifinished & 5.1 & 3.0 & .8 & -.2 & 2.0 & .0 & .2 & -1.0 & -2.0 & -.3 \\
\hline Finished $\ldots \ldots \ldots \ldots \ldots \ldots$ & 4.7 & 2.4 & .3 & .6 & .3 & .4 & .6 & -1.4 & -.2 & -.7 \\
\hline
\end{tabular}

1. Rates of change are calculated as the percent change in the seasonally

2. See footnote 4 to table A.3 adjusted index from the fourth quarter of the previous year to the fourth quarter of the year specified in the column heading.

A.7. Rates of change in electric power use, by industry group, 2000-2004 ${ }^{1}$

\begin{tabular}{|c|c|c|c|c|c|c|c|c|c|c|}
\hline \multirow[t]{2}{*}{ Industry group } & \multicolumn{5}{|c|}{$\begin{array}{l}\text { Revised rate of change } \\
\text { (percent) }\end{array}$} & \multicolumn{5}{|c|}{$\begin{array}{l}\text { Difference between rates of change: } \\
\text { revised minus earlier } \\
\text { (percentage points) }\end{array}$} \\
\hline & 2000 & 2001 & 2002 & 2003 & 2004 & 2000 & 2001 & 2002 & 2003 & 2004 \\
\hline Total industry & 1.0 & -6.4 & -.3 & -1.3 & .8 & .0 & 1.3 & -.8 & 1.4 & -.8 \\
\hline 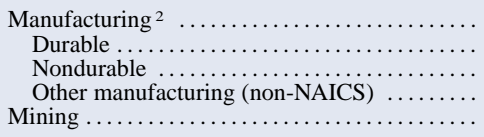 & $\begin{array}{r}1.2 \\
-.1 \\
2.4 \\
-.5 \\
-2.7\end{array}$ & $\begin{array}{l}-6.7 \\
-7.0 \\
-6.4 \\
-6.8 \\
-3.1\end{array}$ & $\begin{array}{r}1.1 \\
-1.0 \\
-2.3 \\
-5.0\end{array}$ & $\begin{array}{r}-1.2 \\
-2.5 \\
-.2 \\
.2 \\
-3.4\end{array}$ & $\begin{array}{r}.7 \\
2.6 \\
-.9 \\
-1.1 \\
2.8\end{array}$ & $\begin{array}{l}.0 \\
.0 \\
.0 \\
.0 \\
.0\end{array}$ & $\begin{array}{r}1.4 \\
1.2 \\
1.5 \\
.0 \\
.1\end{array}$ & $\begin{array}{r}-.8 \\
-.7 \\
-.9 \\
.0 \\
-.4\end{array}$ & $\begin{array}{r}1.6 \\
1.2 \\
1.9 \\
-.6 \\
-1.0\end{array}$ & $\begin{array}{r}-.9 \\
-.2 \\
-1.3 \\
-1.3 \\
.3\end{array}$ \\
\hline $\begin{array}{l}\text { Total excluding nuclear nondefense } \ldots \ldots \ldots \ldots \ldots \\
\text { Utility sales to industry } \ldots \ldots \ldots \ldots \ldots \ldots \ldots \ldots \\
\text { Industrial generation } \ldots \ldots \ldots \ldots \ldots \ldots \ldots \ldots \ldots\end{array}$ & $\begin{array}{r}.2 \\
.6 \\
9.1\end{array}$ & $\begin{array}{r}-5.4 \\
-7.4 \\
2.8\end{array}$ & $\begin{array}{l}-.4 \\
-.3 \\
.7\end{array}$ & $\begin{array}{r}-1.1 \\
-1.5 \\
.9\end{array}$ & $\begin{array}{l}.8 \\
.8 \\
.7\end{array}$ & $\begin{array}{l}.0 \\
.0 \\
.0\end{array}$ & $\begin{array}{l}1.3 \\
1.2 \\
2.6\end{array}$ & $\begin{array}{r}-.8 \\
-.7 \\
-1.4\end{array}$ & $\begin{array}{l}1.4 \\
1.5 \\
-.1\end{array}$ & $\begin{array}{r}-.5 \\
-.6 \\
.7\end{array}$ \\
\hline
\end{tabular}

NotE. Estimates for the third quarter of 2004 are subject to further revision in the upcoming monthly releases.

1. Rates of change are calculated as the percent change in the seasonally

of the year specified in the column heading. For 2004, the rates are calculated from the fourth quarter of 2003 to the third quarter of 2004 and are annualized.

adjusted index from the fourth quarter of the previous year to the fourth quarter

2. See footnote 4 to table A.3. 
A.8. Annual proportion in industrial production, by market groups and industry groups, 1996-2004

\begin{tabular}{|c|c|c|c|c|c|c|c|c|c|c|}
\hline Item & $\begin{array}{l}\text { NAICS } \\
\text { code }^{1}\end{array}$ & 1996 & 1997 & 1998 & 1999 & 2000 & 2001 & 2002 & 2003 & 2004 \\
\hline Total industry & $\ldots$ & 100.0 & 100.0 & 100.0 & 100.0 & 100.0 & 100.0 & 100.0 & 100.0 & 100.0 \\
\hline \multicolumn{11}{|l|}{ MARKET GROUPS } \\
\hline Final products and nonindustrial supplies ...... & $\ldots$ & 56.4 & 56.9 & 58.1 & 57.7 & 57.6 & 59.1 & 58.8 & 58.4 & 58.0 \\
\hline Consumer goods $\ldots \ldots \ldots \ldots \ldots \ldots \ldots \ldots$ & $\ldots$ & 27.7 & 27.6 & 28.0 & 28.2 & 28.5 & 30.1 & 30.9 & 30.9 & 30.3 \\
\hline Durable...$\ldots \ldots \ldots \ldots \ldots \ldots$ & $\ldots$ & 7.8 & 7.9 & 7.9 & 8.0 & 7.8 & 8.1 & 8.9 & 8.8 & 8.4 \\
\hline Automotive products ... & $\ldots$ & 3.6 & 3.7 & 3.7 & 3.9 & 3.7 & 4.0 & 4.6 & 4.7 & 4.5 \\
\hline Home electronics ............ & $\ldots$ & .4 & .4 & .4 & 4 & .4 & .4 & .3 & .4 & .3 \\
\hline Appliances, furniture, carpeting . & $\ldots$ & 1.4 & 1.4 & 1.4 & 1.4 & 1.4 & 1.4 & 1.5 & 1.4 & 1.4 \\
\hline Miscellaneous goods ............ & $\ldots$ & 2.4 & 2.4 & 2.4 & 2.4 & 2.3 & 2.3 & 2.4 & 2.3 & 2.3 \\
\hline Nondurable...$\ldots \ldots \ldots \ldots$ & $\cdots$ & 19.9 & 19.7 & 20.1 & 20.2 & 20.7 & 22.0 & 22.0 & 22.1 & 21.8 \\
\hline Non-energy $\ldots \ldots \ldots$ & $\ldots$ & 16.3 & 16.3 & 16.9 & 16.7 & 16.9 & 18.1 & 18.1 & 17.9 & 17.7 \\
\hline Foods and tobacco & $\ldots$ & 8.7 & 8.7 & 9.2 & 9.1 & 9.3 & 10.0 & 9.7 & 9.7 & 9.7 \\
\hline Clothing ............. & $\ldots$ & 1.8 & 1.6 & 1.5 & 1.3 & 1.2 & 1.1 & 9 & 8 & .7 \\
\hline Chemical products & $\ldots$ & 3.7 & 3.7 & 3.8 & 3.8 & 3.9 & 4.5 & 4.9 & 4.9 & 4.8 \\
\hline Paper products .... & $\cdots$ & 1.7 & 1.8 & 1.9 & 1.9 & 2.0 & 2.0 & 2.0 & 2.0 & 2.0 \\
\hline Energy .............. & $\cdots$ & 3.7 & 3.4 & 3.3 & 3.5 & 3.8 & 3.8 & 3.9 & 4.2 & 4.1 \\
\hline Business equipment & $\ldots$ & 11.2 & 11.8 & 12.3 & 11.9 & 11.7 & 11.2 & 10.3 & 9.9 & 10.0 \\
\hline Transit .................. & $\cdots$ & 1.8 & 2.1 & 2.5 & 2.3 & 2.0 & 2.0 & 1.9 & 1.7 & 1.8 \\
\hline Information processing & $\cdots$ & 3.7 & 4.0 & 4.0 & 4.1 & 4.1 & 3.8 & 3.0 & 3.1 & 2.9 \\
\hline Industrial and other .......... & $\cdots$ & 5.7 & 5.8 & 5.8 & 5.5 & 5.6 & 5.4 & 5.3 & 5.1 & 5.3 \\
\hline Defense and space equipment & $\ldots$ & 2.0 & 1.9 & 1.9 & 1.8 & 1.5 & 1.8 & 1.8 & 2.0 & 2.0 \\
\hline Construction supplies . & $\ldots$ & 4.1 & 4.1 & 4.3 & 4.3 & 4.3 & 4.3 & 4.3 & 4.3 & 4.4 \\
\hline Business supplies ..... & $\cdots$ & 11.0 & 11.1 & 11.2 & 11.2 & 11.2 & 11.3 & 11.2 & 11.0 & 10.9 \\
\hline Materials ..... & $\ldots$ & 43.6 & 43.1 & 41.9 & 42.3 & 42.4 & 40.9 & 41.2 & 41.6 & 42.0 \\
\hline Non-energy & $\cdots$ & 33.4 & 33.8 & 33.3 & 33.1 & 32.3 & 30.8 & 30.9 & 30.2 & 30.1 \\
\hline Durable ............ & $\ldots$ & 21.4 & 21.7 & 21.4 & 21.4 & 20.9 & 19.6 & 19.3 & 18.7 & 18.8 \\
\hline Consumer parts ..... & $\ldots$ & 4.1 & 4.2 & 4.2 & 4.4 & 4.1 & 3.8 & 4.1 & 4.1 & 4.0 \\
\hline Equipment parts .......... & $\ldots$ & 8.1 & 8.3 & 8.2 & 8.1 & 8.1 & 7.3 & 6.7 & 6.2 & 6.2 \\
\hline Other $\ldots \ldots \ldots$ & $\ldots$ & 9.2 & 9.2 & 9.1 & 8.9 & 8.6 & 8.4 & 8.5 & 8.4 & 8.6 \\
\hline Nondurable .... & $\ldots$ & 12.1 & 12.1 & 11.9 & 11.7 & 11.4 & 11.3 & 11.6 & 11.5 & 11.3 \\
\hline Textile $\ldots \ldots \ldots \ldots \ldots \ldots$ & $\ldots$ & 1.1 & 1.1 & 1.0 & 1.0 & .9 & .8 & .8 & .7 & 6 \\
\hline Paper $\ldots \ldots \ldots \ldots \ldots \ldots \ldots$ & $\ldots$ & 3.0 & 2.9 & 2.8 & 2.9 & 2.8 & 2.8 & 2.8 & 2.7 & 2.6 \\
\hline Chemical & $\ldots$ & 4.8 & 4.9 & 4.6 & 4.5 & 4.3 & 4.2 & 4.5 & 4.5 & 4.5 \\
\hline Energy $\ldots \ldots \ldots \ldots \ldots \ldots \ldots \ldots$ & $\cdots$ & 10.2 & 9.3 & 8.6 & 9.2 & 10.1 & 10.0 & 10.3 & 11.4 & 11.9 \\
\hline \multicolumn{11}{|l|}{ INDUSTRY GROUPS } \\
\hline Manufacturing $^{2} \ldots \ldots \ldots \ldots \ldots$ & & 84.4 & 85.7 & 86.5 & 85.8 & 84.5 & 84.1 & 83.8 & 82.5 & 81.9 \\
\hline Manufacturing (NAICS) & $31-33$ & 80.3 & 81.2 & 81.8 & 81.0 & 79.6 & 79.2 & 79.0 & 77.7 & 77.2 \\
\hline Durable manufacturing & & 45.5 & 46.5 & 47.1 & 46.6 & 45.5 & 44.2 & 43.7 & 42.7 & 42.8 \\
\hline Wood products........$\ldots$ & 321 & 1.5 & 1.5 & 1.5 & 1.6 & 1.4 & 1.4 & 1.5 & 1.5 & 1.6 \\
\hline Nonmetallic mineral products & 327 & 2.2 & 2.2 & 2.3 & 2.3 & 2.2 & 2.3 & 2.3 & 2.2 & 2.2 \\
\hline Primary metal .............. & 331 & 3.0 & 3.1 & 2.9 & 2.8 & 2.5 & 2.3 & 2.4 & 2.5 & 2.8 \\
\hline Fabricated metal products... & 332 & 6.0 & 6.0 & 6.1 & 6.0 & 6.1 & 5.9 & 5.8 & 5.6 & 5.7 \\
\hline Machinery $\ldots \ldots \ldots \ldots \ldots \ldots$ & 333 & 6.2 & 6.2 & 6.2 & 5.8 & 5.9 & 5.6 & 5.4 & 5.2 & 5.5 \\
\hline Computer and electronic products .... & 334 & 10.0 & 10.4 & 10.3 & 10.3 & 10.3 & 9.2 & 7.9 & 7.6 & 7.4 \\
\hline Electrical equipment, appliances, & & & & & & & & & & \\
\hline and components $\ldots \ldots \ldots \ldots$ & 335 & 2.6 & 2.6 & 2.6 & 2.5 & 2.5 & 2.4 & 2.2 & 2.1 & 2.1 \\
\hline Motor vehicles and parts ......... & $3361-3$ & 6.5 & 6.7 & 6.6 & 7.0 & 6.6 & 6.5 & 7.4 & 7.5 & 7.2 \\
\hline Aerospace and miscellaneous & & & & & & & & & & \\
\hline transportation equipment & 3364-9 & 3.2 & 3.5 & 4.1 & 3.8 & 3.3 & 3.8 & 3.6 & 3.5 & 3.6 \\
\hline Furniture and related products & 337 & 1.5 & 1.6 & 1.7 & 1.7 & 1.7 & 1.7 & 1.8 & 1.7 & 1.7 \\
\hline Miscellaneous ................... & 339 & 2.8 & 2.8 & 2.8 & 2.8 & 2.9 & 3.1 & 3.3 & 3.2 & 3.1 \\
\hline Nondurable manufacturing $\ldots \ldots \ldots \ldots$ & & 34.7 & 34.7 & 34.7 & 34.4 & 34.1 & 35.0 & 35.3 & 35.0 & 34.4 \\
\hline Food, beverage, and tobacco products & 311,2 & 10.1 & 10.1 & 10.6 & 10.4 & 10.7 & 11.4 & 11.3 & 11.4 & 11.4 \\
\hline Textile and product mills $\ldots \ldots \ldots \ldots \ldots$ & 313,4 & 1.7 & 1.7 & 1.6 & 1.5 & 1.4 & 1.3 & 1.3 & 1.2 & 1.1 \\
\hline Apparel and leather $\ldots \ldots \ldots \ldots \ldots \ldots$ & 315,6 & 1.9 & 1.8 & 1.6 & 1.4 & 1.3 & 1.2 & 1.0 & .8 & .7 \\
\hline Paper $\ldots \ldots \ldots \ldots \ldots \ldots \ldots \ldots \ldots$ & 322 & 3.3 & 3.2 & 3.2 & 3.2 & 3.2 & 3.1 & 3.1 & 3.1 & 3.0 \\
\hline Printing and support $\ldots \ldots \ldots \ldots \ldots$ & 323 & 2.7 & 2.6 & 2.6 & 2.6 & 2.6 & 2.6 & 2.5 & 2.3 & 2.2 \\
\hline Petroleum and coal products ...... & 324 & 1.6 & 1.6 & 1.5 & 1.7 & 1.9 & 1.7 & 1.6 & 1.9 & 2.0 \\
\hline Chemical ........................ & 325 & 9.9 & 10.1 & 9.9 & 9.6 & 9.4 & 9.8 & 10.6 & 10.6 & 10.5 \\
\hline Plastics and rubber products .. & 326 & 3.6 & 3.7 & 3.7 & 3.8 & 3.7 & 3.7 & 3.8 & 3.7 & 3.6 \\
\hline Other manufacturing (non-NAICS) & 1133,5111 & 4.1 & 4.4 & 4.7 & 4.8 & 4.9 & 5.0 & 4.8 & 4.8 & 4.7 \\
\hline Mining ......... & 21 & 6.0 & 5.4 & 4.8 & 5.5 & 6.5 & 6.4 & 6.4 & 7.6 & 8.3 \\
\hline Utilities ......... & 2211,2 & 9.6 & 9.0 & 8.7 & 8.6 & 9.0 & 9.5 & 9.7 & 9.9 & 9.8 \\
\hline Electric .... & 2211 & 8.1 & 7.7 & 7.5 & 7.4 & 7.6 & 8.1 & 8.3 & 8.2 & 8.1 \\
\hline Natural gas & 2212 & 1.4 & 1.3 & 1.2 & 1.2 & 1.4 & 1.4 & 1.5 & 1.6 & 1.6 \\
\hline
\end{tabular}

Note. The IP proportion data are estimates of the industries' relative contributions to the overall IP change between the reference year and the following year. For example, a 1 percent increase in durable goods manufacturing between

1. North American Industry Classification System.

2. See footnote 4 to table A.3. 2004 and 2005 would account for a 0.428 percent increase in total IP.

... Not applicable. 